\title{
NO LONGER JUST CHILD'S PLAY: SCHOOL \\ LIABILITY UNDER TITLE IX FOR PEER \\ SEXUAL HARASSMENT
}

\author{
MONICA L. SHERER†
}

\section{INTRODUCTION}

"Suzy Smith is a slut" was scribbled on the boys' bathroom stall. ${ }^{1}$ The vulgar writing was a daily humiliation for Suzy: nasty comments about "the Suzy stall" from her male classmates and harassing phone calls at home. ${ }^{2}$ Despite numerous protests, the scribbling continued: "Suzy Smith is a whore. Suzy Smith fucks farm animals. Suzy Smith is a dick-sucking brother-fucking whore."3 Only after sixteen complaints did the high school's authorities order the graffiti's removal, eighteen months after Suzy Smith's torment began. ${ }^{4}$

In the aftermath of the Clarence Thomas Supreme Court confirmation hearings ${ }^{5}$ and the Tailhook scandal ${ }^{6}$, American

† B.S. 1991, State University of New York at Binghamton; J.D. Candidate 1994, University of Pennsylvania. With love, I dedicate this Comment to the best teachers that I know-my parents. Thank you for always being my biggest supporters. I am particularly grateful to Veenita Bhatia for being a constant source of help and encouragement. Finally, I would like to thank Todd Izzo for initially drawing my attention to this subject, Professor Susan Sturm for her helpful comments, and my colleagues on the Law Review for their assistance.

${ }^{1}$ Adrian N. LeBlanc, Harassment in the Halls, SEVENTEEN, Sept. 1992, at 162, 163. The young woman's real name has been changed in this Comment.

2 See id. 90.

${ }^{3}$ Katherine Lanpher, Reading, 'Riting, and 'Rassment, Ms., May-June 1992, at 90 ,

${ }^{4}$ See id.

5 In the fall of 1991, law professor Anita Hill testified against Supreme Court nominee Clarence Thomas at his confirmation hearings, charging him with sexual harassment. The hearings, which were televised, sparked a national debate on the concept of sexual harassment. See generally Ann Hodges, Thomas vs. Hill: Proceedings Turn TV into Magnets, Hous. CHRON., Oct. 15, 1991, at A19; Neil A. Lewis, Law Professor Accuses Thomas of Sexual Harassment in 1980's, N.Y. TIMES, Oct. 7, 1991, at A1; Sherry Stripling \& Marsha King, Sex Harassment Now the Talk of the Town, SEATTLE TIMES, Oct. 9, 1991, at A1; Marjorie Williams, From Women, an Outpouring of Anger: $R$ hetoric Underscores Deep Divisions in How the Sexes View Harassment, WASH. POST, Oct. 9, 1991, at A1.

${ }^{6}$ Women allegedly were molested, abused, and harassed during a raucous September 1991 naval aviators' convention known as "Tailhook' 91. ." When a female Navy lieutenant made her complaint public, it set off a top-level probe of the convention as well as of sexual harassment and abuse generally throughout the Navy. It also resulted in congressional hearings, the resignation of the Secretary of the Navy, 
society has been forced to confront the problem of sexual harassment in the workplace. ${ }^{7}$ Heightened awareness about workplace harassment has led to a growing recognition that sexual harassment exists in our nation's schools ${ }^{8}$ as well-in hallways, on the playground, in math class, during band practice, and in the parking lot. $^{9}$ The following scenarios are, sadly, not uncommon in daily school life.

A young woman in the eighth grade is writing out her last will and testament. She leaves her stuffed animals to her mother and her record collection to her best friends. Life seems unbearable because the school day has become a living hell. The boys have been incessantly taunting her about the size of her breasts to the point where she cannot face them again at school. She would walk to school and, all of a sudden, she would hear the word "moo" bellowing out from a group of boys. This behavior occurred before school, after school, between classes, during classes, and at lunchtime. Her mother complained but the school refused to take any action. The school board's response: "boys will be boys."10

and a Pentagon investigation. See generally Melissa Healy, Wide Range of Victims in Wake of Tailhook Scandal, L.A. TIMES, Nov. 1, 1992, at A1; Melissa Healy \& H.G. Reza, Tailhook Probe Finds Lurid Cases of Sexual Misconduct, L.A. TIMES, Feb. 6, 1993, at Al; Nancy Ann Jeffrey, Rankling the Ranks: The Battle Over Sexual Harassment Rages on in the Military, CHI. TRIB., Nov. 1, 1992, at 4.

${ }^{7}$ A recent survey of 607 women conducted by the National Association for Female Executives found that $60 \%$ had experienced sexual harassment-up seven percent from a poll taken right after the Thomas hearings. See Troy Segal et al., Getting Serious About Sexual Harassment, BUS. WK., Nov. 9, 1992, at 78, 78. In December 1988 , Working Woman magazine published a survey showing that almost $90 \%$ of the Fortune 500 companies have received sexual harassment complaints, over a third have had lawsuits filed against them, and nearly a fourth have been repeatedly sued. See Ronni Sandroff, Sexual Harassment in the Fortune 500, WORKING WOMAN, Dec. 1988, at 69,69 .

8 Throughout this Comment, "school" refers to high school, junior high or middle school, and elementary school. It does not refer to colleges or universities. Sexual harassment in higher education is beyond the scope of this Comment. Although public colleges and universities are subject to Title IX, a discussion of sexual harassment in higher education involves different considerations and analysis. See sources cited infra note 13.

${ }^{9}$ See generally Jane Gross, Schools Are Newest Arenas for Sex-Harassment Issues, N.Y. TIMES, Mar. 11, 1992, at B8. Clearly, school sexual harassment is beginning to be acknowledged and treated as a legitimate concern, as evidenced by the recent legislation passed by both Minnesota and California. See infra notes 111-24 and accompanying text.

10 This scenario represents the facts in a complaint brought by Tawnya Brawdy. See Ann Frantz, Suit Seeks Halt to Peer Harassment in Schools, ARGUs-Courier (Petaluma, Cal.), Feb. 20, 1992, at 1, 11; Sally Jessy Raphael: "My 7-Year-Old was Sexually Harassed at School" (ABC television broadcast, Oct. 14, 1992) [hereinafter Sally 
"Friday flip-up day" is a long-standing tradition at a Montana elementary school. It is a competition among boys to see how many girls' skirts they can lift up. ${ }^{11}$

A high school girl is forced to transfer out of her computer class because she is continually taunted by a group of boys using suggestive remarks. The teacher has no control over the class and the other girls are afraid to say anything. ${ }^{12}$

Over the last two decades, the issue of sexual harassment in education has begun to receive more attention as a legitimate problem, spurred on, in part, by the battle being waged against harassment in the workplace. Despite the prevalence of sexual harassment at all levels of education, the legal and nonlegal literature, reports, and studies focus primarily on sexual harassment in higher education. ${ }^{13}$ Rarely does sexual harassment in elementary and secondary schools come to public attention except in the rare instance of a teacher dismissal for sexual abuse of a schoolchild. ${ }^{14}$

Jessy] (transcript on file with author).

1 See Jerry Adler \& Debra Rosenberg, Must Boys Always Be Boys?, NewsweEk, Oct. 19,1992 , at $77,77$.

${ }^{12}$ See Gross, supra note 9, at B8.

13 See generally BILlIE W. DzIECH \& LINDA WEINER, THE Lecherous Professor: SEXUAL HARASSMENT ON CAMPUS (1984) (discussing sexual harassment of college women); Ivory Power: SEXUal Harassment on CAMPus (Michele A. Paludi ed., 1990) (discussing sexual and gender harassment by male faculty members on college campuses); Michele A. PAludi \& Richard B. BARICKMAN, ACAdEMIC AND WORKPLACE SEXUAL HARASSMENT: A RESOURCE MANUAL (1991) (documenting sexual harassment in the workplace and on college campuses); Ronna G. Schneider, Sexual Harassment and Higher Education, 65 TEx. L. REV. 525 (1987) (analyzing Title IX actions against college faculty members). Cf. Patricia L. Winks, Legal Implications of Sexual Contact Between Teacher and Student, 11 J.L. \& EDuc. 437, 443-47 (1982) (discussing sexual harassment in secondary schools and college).

One study reveals that $12.7 \%$ of 246 graduate women surveyed reported that they had been sexually harassed; $21 \%$ had not enrolled in a course to avoid such behavior; $11.3 \%$ tried to report the behavior; $2.6 \%$ dropped a course because of it; and $15.9 \%$ reported being directly assaulted. See PAludi \& BARICKMaN, supra, at 11 (citing N. Bailey \& M. Richards, Tarnishing the Ivory Tower: Sexual Harassment in Graduate Training Programs (Aug. 1985) (paper presented at the Annual Meeting of the American Psychological Association, Los Angeles, Cal.)). In 1986, Cornell University surveyed its women students and found that $78 \%$ of those responding had experienced one or more forms of peer harassment, including sexist comments and unwelcome attention. See id. at 12. MIT also conducted a study of peer harassment and reported that $92 \%$ of the women surveyed had been harassed by male students. See id. At the University of Rhode Island, $70 \%$ of the women surveyed reported instances of peer harassment. See id.

${ }^{14}$ See, e.g., Monica Davey et al., Teacher Jailed on Sex Charges, ST. PETERSBurg TIMES, Oct. 29, 1992, at B1; Sam Dillon, At Least 8 More Students Accuse School Leader of Sexual Abuse, N.Y. TIMES, Dec. 23, 1992, at B3; Ex-Teacher Gets 2 Years for Molesting 
Incidents of peer or student-to-student sexual harassment ${ }^{15}$ occur frequently in elementary and secondary schools, ${ }^{16}$ yet are usually absent from discussions on sexual harassment. Only recently can one find any published material on the existence of peer sexual harassment. Although discourse on harassment has been limited, students in high schools, middle schools, and even elementary schools are now following the lead of those in the workplace and on college campuses, and legally challenging sexually harassing behavior that has been accepted as the status quo. ${ }^{17}$ As sexual harassment becomes a cognizable legal claim in other contexts, students and their parents are less disposed to accept harassment as a normal part of growing up.

Few laws prohibit sexual harassment specifically; usually sexual harassment is challenged within the structure of existing sexdiscrimination laws, such as Title VII of the 1964 Civil Rights Act ("Title VII") ${ }^{18}$ and Title IX of the Education Amendments of 1972 ("Title IX"). ${ }^{19}$ Title VII was designed to prevent discrimination on

11 Girls, L.A. Times, Jan. 6, 1993, at B2; Carlos V. Lozano, Ventura School Board Fires Teacher in Sex Case, L.A. TrMEs, Nov. 12, 1992, at B11.

Teacher-student sexual harassment is a serious problem. One study of high school students reported a 30\% harassment rate by teachers. See Susan Strauss, Sexual Harassment in the School: Legal Implications for Principals, NAT'L ASS'N OF SECONDARY SCH. PRINCIPAls Bull., Mar. 1988, at 93, 95 (1988); see also Dan H. Wishnietsky, Reported and Unreported Teacher-Student Sexual Harassment, 84 J. EDUC. REs. 164 (1991); Dale Mezzacappa, When the Music Stopped, PHILA. INQUIRER, May 19, 1991, Magazine, at 25 (reporting the story of a nationally acclaimed Philadelphia high school orchestra teacher who sexually harassed numerous female students). Teacher-student harassment, however, is beyond the scope of this Comment.

15 Throughout this Comment, "peer" harassment and "student-to-student" harassment are used interchangeably.

${ }^{16}$ See infra notes 40-49 and accompanying text.

${ }^{17}$ See, e.g., infra text accompanying notes 143-44 (discussing the case of the youngest person ever to file a complaint of sexual harassment).

${ }^{18} 42$ U.S.C. $\$ \S 2000$ e-2000e-17 (1988). Title VII provides in pertinent part:

It shall be an unlawful employment practice for an employer ... to discriminate against any individual with respect to his compensation, terms, conditions, or privileges of employment, because of such individual's . . sex ... ; or to limit, segregate, or classify his employees or applicants for employment in any way which would deprive or tend to deprive any individual of employment opportunities or otherwise adversely affect his status as an employee, because of such individual's ... sex ....

Id. $\$ 2000 \mathrm{e}-2(\mathrm{a})(1)-(2)$.

1920 U.S.C. $\$ \S 1681-86$ (1988). Title IX provides, in part: "No person in the United States shall, on the basis of sex, be excluded from participation in, be denied the benefits of, or be subjected to discrimination under any educational program or activity receiving Federal financial assistance .... . Id. \$ 1681(a). Title IX defines an educational institution as "any public or private preschool, elementary, or secondary 
the basis of race, sex, religion, color, and national origin in the workplace; Title IX was intended to discourage discrimination on the basis of sex in educational programs. A significant body of case law has developed regarding workplace sexual harassment since the courts first recognized it as a cause of action under Title VII. ${ }^{20}$ Relatively few Title IX cases, however, have addressed sexual harassment. Consequently, few judicial and administrative standards on sexual harassment have been developed under Title IX. To date, no Title IX cases have involved purely student-to-student sexual harassment.

Title IX is usually invoked in connection with issues such as equality in sports programs and equal access to vocational/technical classes. ${ }^{21}$ In February 1992, the Supreme Court ruled that students may recover monetary damages for violations of Title IX. ${ }^{22}$ That decision could convert the little-used twenty-one-year-old law into a powerful new weapon against sexual harassment in schools. The case involved a high school student who alleged she was subjected to continual sexual harassment and abuse by her teacher. This Comment argues that by analogy to the workplace, where courts have held companies liable if their employees create a "hostile environment" ${ }^{\text {"23 }}$ for co-workers, the principles embodied in Title VII and Title IX should be extended to hold federally funded elementary and secondary schools liable under Title IX where incidents of peer sexual harassment create a similarly hostile environment and deny the harassed classmates an equal-opportunity education. ${ }^{24}$

school, or any institution of vocational, professional, or higher education." Id. $\S 1681$ (c).

${ }^{20}$ The District of Columbia Circuit was the first court of appeals to hold Title VII applicable to a claim alleging that a supervisor conditioned a job promotion on sexual favors. See Barnes v. Costle, 561 F.2d 983, 990 (D.C. Cir. 1977).

${ }^{21}$ See, e.g., Yellow Springs Exempted Village Sch. Dist. Bd. of Educ. v. Ohio High Sch. Athletic Ass'n, 647 F.2d 651, 655 (6th Cir. 1981) (invoking Title IX in a case involving inequality in sports programs); Canterino v. Barber, 564 F. Supp. 711, 715 (W.D. Ky. 1983) (invoking Title IX in a case involving unequal access to vocational classes).

22 See Franklin v. Gwinnett County Pub. Sch., 112 S. Ct. 1028, 1038 (1992).

${ }^{25}$ For a definition of "hostile environment," see infra notes 28,33 and accompanying text.

24 It is important to note here that this Comment proposes that the school, not the student-harasser, be held liable under the proposed prima facie case to make out a claim for peer sexual harassment. Under this Comment's proposal, a school will only be held liable for a proven sexual harassment claim if the school officials knew or should have known of the harassment and failed to take any remedial action. See 
Part I of this Comment summarizes the legal, theoretical, and operational definitions of sexual harassment. Part I then proceeds to explain and analyze the problem of student-to-student sexual harassment in elementary and secondary schools. A clear understanding of the serious nature and consequences of peer sexual harassment is necessary before considering the liability of schools under Title IX. ${ }^{25}$ Part II describes and assesses how peer sexual harassment is being dealt with on the local and state levels. A small number of schools have voluntarily implemented, albeit to varying extents, guidelines regarding sexual harassment in school. Two states have passed legislation. Part II illustrates that the local and state remedies are often insufficient or nonexistent. Thus, an investigation of a federal statutory solution is required. Part III details and evaluates the Title IX statutory and regulatory scheme. Part IV demonstrates that student-to-student sexual harassment is a violation of Title IX in that it constitutes differential treatment on the basis of sex. Finally, Part V illustrates that student-to-student sexual harassment creates a hostile environment similar to the hostile environment recognized under Title VII. Adapting Title VII standards, Part V also proposes the prima facie elements of a Title IX hostile educational environment sexual harassment claim that would hold a school liable for its failure to remedy repeated incidents of peer sexual harassment. This Comment concludes that Title IX sexual harassment claims should be expanded into the public school arena to redress the effects of student-to-student sexual harassment. Moreover, it advocates the use of Title IX as a means to communicate to males and females that sexual harassment is simply wrong and, thus, intolerable.

infra text accompanying notes 240-46. Under most circumstances, one or two isolated incidents such as a catcall or sexual epithet will not constitute a cognizable legal claim for sexual harassment. For an explanation of the elements that make out a claim for student-to-student sexual harassment under the proposal, see infra part V.B.

${ }^{25}$ Throughout this Comment, I review the factual basis for the sexual harassment claims. Though I realize that a detailed review of the particular facts of these cases may well be offensive to some readers, an appreciation of what has actually been said and done in these school environments is indispensable to a realistic understanding of the issues of peer sexual harassment cases. 


\section{Sexual harassment: A Problem for ELEMENTARY AND SECONDARY SCHOOL STUDENTS}

\section{A. Defining Sexual Harassment}

Any meaningful discussion of peer sexual harassment requires a workable definition of sexual harassment. Indeed, many of the problems arising from the issue of sexual harassment stem from the fact that there is no clear, concise, widely accepted definition of the term. ${ }^{26}$ The following survey of sexual harassment definitions that have been advanced reveals a general concern for the workplace and academic environment but little consensus on the substance that defines the boundaries of sexual harassment. Lack of conformity, in part, derives from the objectives of the definition-legal, theoretical, or operational.

Sexual harassment is a particular form of sex discrimination. In September 1980, the Equal Employment Opportunity Commission $(\text { "EEOC" })^{27}$ issued guidelines recognizing that sexual harassment in the workplace is a form of discrimination prohibited by Title VII. The guidelines defined sexual harassment as:

[u]nwelcome sexual advances, requests for sexual favors, and other verbal or physical conduct of a sexual nature ... when (1) submission to such conduct is made either explicitly a term or condition of an individual's employment, (2) submission to or rejection of such conduct by an individual is used as the basis for employment decisions affecting such individual, or (3) such conduct has the purpose or effect of unreasonably interfering with an individual's work performance or creating an intimidating, hostile, or offensive working environment. ${ }^{28}$

${ }^{26}$ In fact, Catharine Mackinnon, a law professor and expert in the area of sexual harassment, argues that the lack of a definition for sexual harassment helps explain why historically women have not protested sexual harassment. She notes that "[i]t is not surprising . . . that women would not complain of an experience for which there has been no name. Until 1976, lacking a term to express it, sexual harassment was literally unspeakable, which made a generalized, shared, and social definition of it inaccessible." CATHARINE A. MACKINNON, SEXUAL HARASSMENT OF WORKING WOMEN 27 (1979) (footnote omitted).

${ }_{27}$ The EEOC is the administrative agency charged with enforcing Title VII. See 42 U.S.C. $§ 2000 \mathrm{e}-4$ (1988); Exec. Order No. 12067, 3 C.F.R. 206 (1979), reprinted in 42 U.S.C. $\$ 2000 \mathrm{e}(1988)$.

2829 C.F.R. § 1604.11(a) (1992). 
In an August 1981 policy memorandum, the Office for Civil Rights ("OCR") ${ }^{29}$ of the U.S. Department of Education adopted its own definition of sexual harassment:

"[s] exual harassment consists of verbal or physical conduct of a sexual nature, imposed on the basis of sex, by an employee or agent of a recipient that denies, limits, provides different, or conditions the provision of aid, benefits, services or treatment protected under Title IX." ${ }^{30}$

Federal courts recognize two types of sexual harassment: "quid pro quo" and "hostile environment." Quid pro quo harassment occurs when someone in a supervisory position conditions the granting of a tangible benefit upon the receipt of sexual favors from a subordinate or punishes that subordinate for refusing to comply. ${ }^{31}$ A teacher who bribes a student with an " $A$ " on her paper if she will submit to sexual relations with him is engaging in quid pro quo harassment. Hostile-environment harassment is not as explicit but is no less devastating to the victim-harassee. Hostile environment-harassment occurs when an atmosphere is created "so infused with hostility toward members of one sex" that it alters the working or educational environment. ${ }^{32}$ One nursing student's experience clearly depicts hostile-environment harassment: "Playboy centerfolds were used as Anatomy teaching slides.... In slides, lectures, teaching aids and even our own student note service, we found that

${ }^{29} \mathrm{OCR}$ has been delegated the responsibility of reviewing complaints and investigating institutional compliance with Title IX by the Department of Education. See 20 U.S.C. $\$ 3413$ (1988).

30 OFFICE FOR CIVIL RIGHTS, U.S. DEP'T OF EDUC., SEXUAL HARASSMENT: IT'S NOT ACADEMIC 2 (1986) [hereinafter IT'S NOT ACADEMIC] (quoting OCR Policy Memorandum from Antonio J. Califa, Director for Litigation, Enforcement, and Policy Service, to Regional Civil Rights Directors (Aug. 31, 1981)).

${ }^{31}$ See, e.g., Meritor Sav. Bank v. Vinson, 477 U.S. 57, 64-65 (1986) (regarding job security that was conditioned upon submission to employer's sexual demands); Lipsett v. University of P.R., 864 F.2d 881, 897 (1st Cir. 1988) (considering dismissal from medical residency program allegedly because of gender); Alexander v. Yale Univ., 459 F. Supp. 1, 4 (D. Conn. 1977) (considering claims that academic advancement was conditioned upon submission to professor's sexual demands), aff'd, $631 \mathrm{~F} .2 \mathrm{~d} 178$ (2d Cir. 1980).

Quid pro quo literally means "this for that" in Latin. Quid pro quo harassment corresponds to sections (1) and (2) of the EEOC definition of sexual harassment. See supra text accompanying note 28 .

${ }^{32}$ Lipsett, 864 F.2d at 897; see also Vinson, 477 U.S. at 65 (detailing supervisor's demands upon an employee for sexual favors both during and after business hours, as well as touching and fondling of the employee in front of co-workers).

Hostile-environment harassment corresponds to section (3) of the EEOC definition of sexual harassment. See text accompanying supra note 28. 
nurses were presented as sexy, bitchy or bossy but never as professional health care workers. ${ }^{\text {33 }}$

Academic commentators have developed more theoretical statements on sexual harassment as opposed to the above legal and regulatory constructions. ${ }^{34}$ The National Advisory Council on Women's Educational Programs has defined academic sexual harassment as "the use of authority to emphasize the sexuality or sexual identity of the student in a manner which prevents or impairs that student's full enjoyment of education benefits, climate, or opportunities." 35 On a more specific, behavior-oriented level, "unwelcome sexual harassment ranges from unwanted sexual innuendos made at inappropriate times-perhaps even in the guise of humor-to coerced sexual relations. ${ }^{n 6}$ Sexual harassment can embody many forms: verbal harassment such as sexual comments or name calling; leering or ogling; jokes or pictures; unnecessary touching; sexist remarks about a person's clothing, body, or sexual activities; constant brushing up against a person's body; subtle or overt pressure for sexual favors; physical assault; and rape. ${ }^{37}$

These examples illustrate the range of approaches to the definition of sexual harassment, from inclusion of specific proscribed behavior to a general statement describing the nature of the behavior. It is clear that there is no established, uniform definition

33 IT's NOT ACADEMIC, supra note 30, at 7 (footnote omitted).

${ }^{34}$ For example, Catharine MacKinnon defines sexual harassment as "the unwanted imposition of sexual requirements in the context of a relationship of unequal power." MACKInNon, supra note 26, at 1 . The Alliance Against Sexual Coercion, an organization that provides services to women who have experienced sexual harassment in employment and education, defines sexual harassment as "[u]nwanted sexual attention' from peers, subordinates or supervisors or customers, clients or anyone the victim must interact with in order to fulfill job or school duties where the victim's responses are restrained by fear of reprisals." MASSACHUSETTS BD. OF EDUC., WHo's HURT AND WHO'S LIABLE: SEXUAL HARASSMENT IN MASSACHUSETTS SCHOOLS 9 (1986) [hereinafter WHO's HURT AND WHO'S LIABLE] (Curriculum and Guide for School Personnel).

35 WhO'S HURT AND WHO's LIABLE, supra note 34, at 9 (quoting the Advisory Council on Women's Educational Program's definition of sexual harassment in education).

36 Elizabeth Powell, Talking Back to Sexual Pressure 109-10 (1991); see also MACKINNON, supra note 26, at 29 (describing the verbal and physical forms that sexual harassment can comprise).

${ }^{37}$ See POWELL, supra note 36, at 110 (listing behaviors that could constitute sexual harassment); Strauss, supra note 14, at 94 (similar list). For some other definitions developed empirically by investigating what various groups of individuals perceive sexual harassment to be under different circumstances, see PALUDI \& BARICKMAN, supra note 13 , at $6-9$. 
that must be followed by all educational institutions under Title IX. A clearly defined, uniformly operational definition of harassing behavior clarifies the problem of sexual harassment and provides a more effective framework for dealing with it. Definitions of sexual harassment are important because "they can educate the community and promote discussion and conscientious evaluation of behavior and experience. ${ }^{\text {38 }}$ Lack of a uniform definition may hinder the resolution of cases, resulting in schools providing differential treatment of sexual harassment incidents.

\section{B. What is Peer Sexual Harassment?}

"Peer harassment is the term used to describe the sexual harassment of [persons] by their [opposite sex] colleagues-women students harassed by male students, for example; women faculty harassed by male faculty; and gay and lesbian students harassed by other students. ${ }^{39}$ In 1981, the first study conducted by the Massachusetts Department of Education on sexual harassment in high school substantiated the Department's suspicions that peer sexual harassment does in fact occur in school settings. ${ }^{40}$ The research results revealed that student-to-student sexual harassment is far more prevalent than teacher-to-student harassment, ${ }^{41}$ young women are much more likely to be the victim of sexual harassment than young men, ${ }^{42}$ and sexual harassment occurs in both vocation-

${ }^{38}$ Paludi \& Barickman, supra note 13, at 8 (quoting P. Crocker, An Analysis of University Definitions of Sexual Harassment, 8 SIGNS 696, 697 (1983)).

${ }^{39} I d$. at 12 (emphasis omitted).

40 See WHO'S HURT AND WHO's LIABLE, supra note 34, at 1-2 (asserting that sexual harassment incidents in high schools are "common occurrences"). The Department of Education in Massachusetts became aware of the problem of sexual harassment through reports of sexual harassment incidents to teachers, guidance counselors, school administrators, and women's groups. See id. The survey was limited to high school students in Massachusetts. See id.

Very few studies have actually been conducted in elementary and secondary schools. Nan Stein, a sex-equity specialist, however, is currently working on a threeyear project at Wellesley College's Center for Research on Women that will identify and produce case studies on sexual harassment and child abuse in schools. See Esther Shein, Documenting-and Dealing with-Sexual Harassment in School, BosTON GLOBE, June 28,1992 , at 37 . In conjunction with this project, a survey was published in the September 1992 issue of Seventeen magazine that will provide data for the study. See LeBlanc, supra note 1, at 162-65, 170; see also Nan Stein, School Harassment-An Update, EDUC. WK., Nov. 4, 1992, at 37 (describing the initial responses to the survey). The survey promises to be the largest ever conducted on sexual harassment in schools.

41 See WHO's HURT AND WHO's LIABLE, supra note 34, at 2; see also supra note 14.

42 See WHO's HURT AND WHO's LIABLE, supra note 34, at 2. Because young women are more frequently the target of sexual harassment, this Comment will only 
al high schools and comprehensive schools. ${ }^{43}$ The few subsequent surveys, as well as interviews with samples of students and reports made to the Department of Education by victims, their parents, or school personnel, confirm that sexual harassment is commonplace in our schools. ${ }^{44}$ Much of the harassment that the young women experience is in the form of remarks, touching, gestures, and staring. ${ }^{45}$ Complaints have included girls having their breasts grabbed by boys, ${ }^{46}$ boys purposefully rubbing up against girls in the hall between classes, ${ }^{47}$ catcalls and ugly sexual remarks, boys pulling down girls' pants in the middle of the hallway, ${ }^{48}$ and the poking of private body parts with pencils. ${ }^{49}$ Girls are faced with the dilemma of finding ways to either tolerate or avoid these

focus on female adolescents as victims. A study published in 1988 showed that 33 $60 \%$ of 133 responding females reported experiencing some form of sexual harassment. Only one of the 130 males responding reported being the victim of sexual harassment. See Strauss, supra note 14, at 95-96. Nevertheless, peer sexual harassment of adolescent males should not be tolerated. Male victims of sexual harassment experience the same type of direct and indirect effects on their education as female victims.

13 See WHO's HURT AND Who's LIABLE, supra note 34, at 2.

44 See, e.g., Strauss, supra note 14, at 96 (publishing results of questionnaire distributed to a Student Leadership Conference held in May 1986 where $80 \%$ of the respondents indicated they were aware of sexual harassment in their schools); Sexual Harassment Widespread in High Schools, Study Finds, L.A. TIMEs, Jan. 4, 1987, at 26 (reporting that a large percentage of high school students are victims of peer sexual harassment according to researchers at the University of Michigan School of Education who surveyed 15 school districts).

${ }^{45}$ Physical harassment that would not occur but for the sex of the victim may be characterized as sexual harassment. See Hicks v. Gates Rubber Co., 833 F.2d 1406, 1415 (10th Cir. 1987) (holding that physically aggressive but not explicitly sexual acts by a male supervisor against a female employee, if pervasive enough, may constitute sexual harassment) (citing with approval McKinney v. Dole, 765 F.2d 1129, 1138-39 (D.C. Cir. 1985)). Such harassment also appears to be widespread in the school environment. See, e.g., Jane Gross, Where "Boys Will Be Boys," and Adults Are Befuddled, N.Y. Times, Mar. 29, 1993, at A1 (reporting on the "Spur Posse," a group of 20-30 boys in a California high school accused of systematically intimidating, molesting, and raping girls); High School Girls Face Harassment, USA TODAY, Aug. 1992, at 12 ("Nearly $40 \%$ of Wisconsin girls faced physical harassment from teen acquaintances by the time they were high school seniors, and about one-third of them said they were victims of unwanted intercourse in a survey of junior and senior high students in primarily rural areas ....").

46 See Andrea Atkins, Sexual Harassment in School: Is Your Child at Risk?; BETTER HOMES \& GARDENS, Aug. 1992, at 32, 32.

47 See BARBRA MORRIS ET AL., CENTER FOR SEX EQUITY IN SCHOOLS, TUNE IN TO YOUR RIGHTS ...: A GUIDE FOR TEENAGERS AbOUT TURNING OFF SEXUAL. HARASSMENT 5 (1985). Some girls have devised a solution: holding their books tightly in front of them. See id.

48 See Strauss, supra note 14 , at 93.

${ }^{49}$ See Gross, supra note 9, at B8. 
degrading and upsetting behaviors that have become acceptable and ordinary.

The paucity of research and interest in sexual harassment in elementary and secondary schools as compared to higher education may be explained, in part, by the ages of the victims and the harassers. Peer sexual harassment most frequently involves adolescents ${ }^{50}$ whose behavior is often characterized as "harmless adolescent exploration"51 or just raging hormones. Often "misconstrued as a normal rite of passage [or] as awkward 'getting-toknow-you' behaviors," it is thereby trivialized, condoned, or dismissed as "flirting' or 'initiation rites." $\$ 52$

That a student's behavior be fairly recognized as flirting or teasing rather than sexual harassment is a legitimate concern because such a mischaracterization may discourage healthy social/ personal relationships. Adults are themselves uncertain sometimes about what comprises sexual harassment. Boys are becoming even more confused. "Am I allowed to tell Whitney she has beautiful eyes?," asked one young man. ${ }^{53}$ The ability to recognize behaviors that constitute sexual harassment is a necessary initial step toward addressing the issue of sexual harassment. Although flirting and sexual harassment share some similarities such as touch, comments, looks, and gestures, students themselves have pointed out differences in the feelings each behavior elicits. ${ }^{54}$ Flirting feels good, is positive and often complimentary, and makes one feel attractive. ${ }^{55}$ Even annoying one-directional flirting is viewed as not serious. ${ }^{56}$

${ }^{50}$ Although most reported incidents occur in high schools and middle schools, harassment is not uncommon in elementary schools. See infra notes 143-44 and accompanying text.

${ }^{51}$ Gross, supra note 9, at B8 (statement of Bob Giannini, the principal of Monte Vista High School in Danville, California, before examining the problem of peer sexual harassment in his school); cf. Gross, supra note 45, at A13 (reporting that some parents of Spur Posse boys were "downright boastful about their sons").

52 Nan D. Stein, It Happens Here, Too: Sexual Harassment in the Schools, EDUc. WK., Nov. 27, 1991, at 32, 32.

${ }^{53}$ Gross, supra note 9 , at B8.

${ }^{54}$ For example, one respondent said, "Winking is $\mathrm{OK}$, but if there is tongue movement or drooling, that's over the line." Shein, supra note 40, at 39 .

${ }^{55}$ See Strauss, supra note 14, at 94 (surveying high school students on how they distinguish sexual harassment from flirting).

${ }_{56}$ See WHO's HURT AND WHO's LIABLE, supra note 34, at 7 ("Students felt that they were able to discourage unwanted flirtation by making certain comments or behaving in such a way as to dismiss the one-way flirtation."). 
In contrast, students describe sexual harassment as making one feel bad, angry, helpless, degraded, confused, and "cheap. ${ }^{57}$

Analyzing the feelings evoked by sexual harassment is a good way for students to learn how to differentiate flirting from sexual harassment. Incorporating a subjective standard into a definition of sexual harassment, however, is problematic. Any examination of sexual harassment must recognize that learning and developing both academically and emotionally in an educational setting requires interaction between students. An operational definition of sexual harassment must effectively prohibit sexual harassment without chilling student relationships. An objective standard rather than the subjective perception of the victim provides a greater degree of certainty in establishing the contours of prohibited conduct. An objective test also recognizes that not all sexual interaction between students necessarily constitutes illegal sexual harassment. Sexual harassment must be evaluated in light of the surrounding circumstances-the time, place, manner of conduct, and the relationship between the parties. Thus, flirting is merely a label for conduct that a reasonable person believes permissible.

Ambiguity about peer sexual harassment may arise "from the context of certain behaviors, not necessarily the behaviors themselves." ${ }^{58}$ Certain behavior deemed acceptable in social situations will not be appropriate in school settings. One aspect that adult observers tend to overlook is the difference in power between the parties involved. ${ }^{59}$ Normally, power differentials are associated with supervisor/employee or teacher/student relationships, but it also exists between peers. ${ }^{60}$ Power can be derived from belonging to a particular social group, and acceptance by these groups may require enduring uncomfortable behavior from a popular classmate. ${ }^{61}$

Considering that maintaining one's reputation is also important, a student may respond to unwelcome attention with a mark of politeness or friendliness. These dynamics only compound the problem. While an initiator is likely to interpret conformity or politeness as encouragement, the harassee is often confused and

57 See MORRIS ET AL., supra note 47, at 8; Strauss, supra note 14 , at 94.

58 WHO's HURT AND WHO's LIABLE, supra note 34, at 11.

${ }^{59}$ See id.

${ }^{60}$ See id.

61 See id.; $c f$. Gross, supra note 45 , at A13 (reporting that some girls targeted by the Spur Posse were "willing" to have sex with the boys because "[t]hat's how they're trying to get popular"). 
anxiously hopes that the whole problem will go away. The absence of overt conflict may mean that adult observers would tend to view such situations as normal instances of adolescents learning to see themselves as sexual beings and evolving their own values. ${ }^{62}$

These seemingly social behaviors can dissuade a student from taking a course or pursuing a particular career. ${ }^{63}$

Confusion over the definition of peer sexual harassment also derives from differing perceptions of the same interactions by males and females. Recent surveys indicate that men and women disagree on what constitutes sexual harassment and on its effects on an individual's self-esteem and productivity. ${ }^{64}$ Males often perceive sexual harassment as flattery, even if unwanted, whereas females often perceive it as threatening, violative of their personhood, and confusing. ${ }^{65}$ Many males find "talk about sex titillating." females, it can be intimidating, especially in a place where they want to be taken seriously. "It reminds everyone present that she is, first of all, a woman and, secondly, vulnerable." ${ }^{n 67}$ In the classroom, "' $[g]$ irls are learning that they are second-class citizens, only valued for their physical attributes." and vulgar language send a nasty message to a young girl, "focus[ing] negative attention on her changing body." 69 Clear communication can aid in clarifying differences of perception. ${ }^{70}$

62 WHO'S HURT AND WHO's LIABLE, supra note 34, at 11 . In one study, most girls said they ignored the attention because they "didn't want to make waves" or "'were afraid people would think [they were] making a big deal out of nothing." Strauss, supra note 14 , at 95.

63 See WHO's HURT AND WHO's LIABLE, supra note 34, at 11.

64 See id. at 12.

65 See id.; Strauss, supra note 14, at 95. Interestingly, one Los Angeles phone survey revealed that women who were harassed considered themselves on the whole to be of average attractiveness and the men who harassed them to be unattractive. In contrast, men who were harassed believed they were selected as targets for this unwanted attention because of their superior attractiveness and that their harassers were also of superior attractiveness. See WHO'S HURT AND WHO's LIABLE, supra note 34 , at 12.

66 The Price of Saying No, PEOPLE, Oct. 28, 1991, at 49 (quoting Deborah Tannen, linguistics professor at Georgetown University).

67 Id. (quoting Deborah Tannen).

${ }^{68}$ Gross, supra note 9, at B8 (quoting Sharon Schuster, President of the American Association of University Women); cf. Gross, supra note 45, at A13 (reporting some students' speculation on the motives of the girls who acquiesced to the Spur Posse: "They're not the prettiest, you know. . . . So they take whatever they can get.").

${ }^{69}$ Atkins, supra note 46, at 34 (quoting Pam Ryan, Manager of the National Education Association's Sexual Harassment Training and Advocacy Program).

${ }^{70}$ In a recent high school case, some young men wrote sexually abusive language on a young woman's test paper after it had been returned by the teacher, greatly 
"There's a fine line; that's obvious to me now,' one high school student said after a girl explained that she liked being told that her sweater was pretty but not that she had nice breasts." ${ }^{71}$ Females and males must exchange information sufficiently to understand each others' views and beliefs. Understanding the dynamics of sexual harassment requires viewing the world through someone else's eyes.

Sex role expectations add to the ambiguity and dismissal of sexual harassment. In some instances, a female's perception of "normal" male behavior will cause her to justify his harassment as unintentional, or just friendly, or accidental. ${ }^{72}$ A female will often remain silent and look inward for reasons as to why she is feeling embarrassed, humiliated, or angry. ${ }^{73}$ Because sex role expectations are changing, continued sex role stereotyping will confuse male and female interactions. Sex role expectations are learned as are other prejudices, beliefs, and values. The law cannot eliminate private prejudices and stereotypes, but it can provide assistance by prohibiting the expression of such beliefs in public and hopefully, in turn, teaching society that such beliefs are unacceptable in private.

\section{Effects of Peer Sexual Harassment}

Students who are victims of peer sexual harassment report a multitude of consequences. Students experience feelings of embarrassment, fear, anger, frustration, loss of self-confidence, powerlessness, and cynicism about education. ${ }^{74}$ Some experience retaliatory measures for not complying with the harasser's demands. ${ }^{75}$ Peer retaliation may include "sabotaging a school project, spreading rumors, or ostracizing a person from friendship

upsetting her. The student reported the incident to an administrator who spoke with the boys. The young men simply did not consider the effects of their actions upon the young woman. They thought they were merely "teasing" her. When they were asked how they would respond to the same behavior if it had been directed at their girlfriend or sister, however, they were able to see their actions in perspective and the dehumanizing nature of their behavior. See WHO's HURT AND WHO'S LIABLE, supra note 34 , at $12-13$.

${ }^{71}$ Gross, supra note 9.

72 See CARRIE M.H. HERBERT, TAlKING of Silence: The SEXual HaRassment of SCHOOLGIRLS 32 (1989).

73 See id.

74 See MORRIS ET AL., supra note 47, at 8; WHO's HURT AND WHO's LIABLE, supra note 34, at 6; Stein, supra note 52, at 32; Strauss, supra note 14, at 95.

75 See WHO's HURT AND WHO's LIABLE, supra note 34 , at 6. 
networks. ${ }^{\text {76 }}$ Often the emotional responses manifest themselves in physical symptoms including insomnia, listlessness, and depression, ${ }^{77}$ which often results in a reduced ability to perform schoolwork, excessive absenteeism, and frequent tardiness. ${ }^{78}$ Many students have also indicated that sexual harassment affects their ability to remain in the environment. ${ }^{79}$ Sexual harassment has led students to transfer from particular courses or majors, especially in fields considered nontraditional for women, such as auto repair, carpentry, and plumbing, and, in some instances, to withdraw from school. $^{80}$

When sexual harassment is allowed to continue, in addition to feeling "betrayed, discredited, or compromised by peers," victims feel "unsupported by school staff, seem less trusting of people in general, and less enthusiastic about pursuing their education. ${ }^{n 11}$ They may even avoid getting involved in school-sponsored events or activities that may enrich their education. ${ }^{82}$ Sexual harassment leads to diminished educational opportunity for young women. "If sexual harassment is allowed to occur it disrupts the right to equal education by interfering with the student's psychological, social, and physical well-being, plus learning, attendance, course choices, grades, and therefore, economic potential." 83

\footnotetext{
${ }^{76} I d$.

${ }^{77}$ In some extreme cases, it can lead to suicide. See supra text accompanying note 10.

78 See WHO'S HURT AND WHO's LIABLE, supra note 34 , at 6.

79 The following student reports are illustrative:
}

It is a common recurring problem that certain male students make repeated propositions to a female student. These propositions are often accompanied by obscene comments. It has made the person feel very uncomfortable and has influenced attendance.

A young woman was always having comments thrown at her about how big she was.... In one particular class one of the guys kept making comments about her which the teacher went along with. Then this guy started spreading his legs open at her in front of the whole class. She got angry and didn't like to go to that class.

WHO's HURT AND WHO's LIABLE, supra note 34 , at 3.

${ }^{80} \mathrm{See}$ id. at 6 . In the case of Tawnya Brawdy, her friend who was also harassed was forced to change schools. See Sally Jessy, supra note 10, at 2.

${ }^{81}$ Stein, supra note 52, at 32.

82 Surveys of college students who have experienced sexual harassment reported following a "path of self-protection." WHO's HURT AND WHO's LIABLE, supra note 34, at 6. "[T]hey avoided seeking assistance from professors and teaching assistants, and avoided any department-sponsored social situations." Id.

${ }^{83}$ Strauss, supra note 14 , at 93. 
Furthermore, it is equally important to examine the consequences of peer sexual harassment in a larger context. Children must learn how their behavior affects others. ${ }^{84}$ "[I]gnoring certain behavior sends a message of inequality to girls ... and sets the stage for how men and women treat each other as adults." 85 Victims of sexual harassment, as well as bystanders, often express a loss of belief in justice and a caring community. ${ }^{86}$ Men and boys who are not repeatedly challenged in any way about the inappropriateness of their behavior may perceive the behavior to be acceptable or condoned. Ignoring sexual harassment implicitly gives young men permission for it to occur and perpetuates the conduct. In short, challenging the "boys will be boys" attitude and placing a greater emphasis on early education about sexual harassment simply teaches the next generation of adults about respect, dignity, and human decency. ${ }^{87}$

\section{RECOURSE FOR HARASSMENT AT THE LOCAL AND STATE LEVEL}

\section{A. The Local Level}

The United States Department of Education has issued regulations explaining the responsibilities of each recipient of federal financial assistance under Title $\mathrm{IX}^{88}$ The Title IX regulations, inter alia, require institutions to adopt and publish grievance procedures. $^{89}$ There is no affirmative obligation on the educational

${ }^{84}$ One high school sophomore remarked that if a boy yelled directly at a girl in school, "Oh, look at her. I'd like to get some of that," he would not consider it sexual harassment. Molly Warfield, Students Indifferent to Sex Harassment, W. HIGH KoDIAK (High School Newspaper, Billings, Mont.), Oct. 24, 1991, at 9 (quoting a sophomore student). Some people argue that "adult" standards should not be placed on children. Prohibiting sexual harassment, however, should not be viewed as an "adult" or higher standard to meet. Harassers, regardless of age, should be held accountable for their behavior. In other areas, children must conform their behavior to certain standards. For instance, students are not supposed to use vulgarities in the classroom and they cannot possess or use drugs or alcohol on school grounds.

${ }^{85}$ Gross, supra note 9 , at B8.

${ }^{86}$ See Stein, supra note 52, at 32.

87 See generally Tommy Denton, "Boys" Will Be Boys-Unless They're Taught Otherwise, Early and Often, VANCOUVER SUN, Apr. 11, 1992, at B2 ("Shaping good character, after all, is inherent in the classical sense of education.").

${ }^{88}$ See 34 C.F.R. § 106.1-.71 (1992).

${ }^{89}$ See id. \$ 106.8-.9 ("A recipient shall adopt and publish grievance procedures providing for prompt and equitable resolution of student and employee complaints alleging [violations of the regulations]."). 
institution, however, to develop formal policies and procedures for specifically handling sexual harassment cases. The absence of specifically tailored policies makes it more difficult to resolve complaints of sexual harassment, as victims who come forward with complaints in schools lacking policies often find they are not supported by school officials. ${ }^{90}$ It is common for sexual harassment victims to be accused of inventing stories, having ulterior motives, or overreacting. ${ }^{91}$

Some schools have voluntarily implemented sexual harassment policies and procedures. ${ }^{92}$ Approaches that have been initiated include, to differing extents, one or more of the following: developing a specific policy against sexual harassment, disseminating the policy, developing a procedure to inform new students and school employees about the policy, surveying the school to find out the extent of problems, developing and disseminating information about grievance procedures to handle sexual harassment complaints, and developing a code of conduct for students. ${ }^{93}$ The purpose is to identify and remedy sexual harassment cases before they escalate, resolve serious conflicts fairly and quickly, and reduce the overall incidence of sexual harassment. Educators hope the policies and procedures will promote a greater awareness of sexual harassment. ${ }^{94}$

The most controversial measure attempted by school officials is the implementation of sexual harassment codes. The codes establish and define guidelines governing exactly what constitutes sexual harassment. Most explain the consequences of violating the code. Disciplinary actions may include participation in a program or research project on the problem of sexual harassment, a parent

90 See Atkins, supra note 46, at 34.

91 See id.; see also Lanpher, supra note 3, at 91.

92 See, e.g., Craig Anderson, Student Sex-Harass Policy Revised, PrEss DEMOCRAT, Aug. 1, 1992, at B1, B1 ("The proposal [to revise the school sexual harassment policy] includes definitions of sexual harassment, a formal process for hearing complaints, and directions that 'appropriate instruction' on the issue be presented as part of the curriculum.").

${ }^{93}$ See WHO'S HURT AND WHO'S LIABLE, supra note 34, at 24-26 (describing the range of approaches of a model program in Massachusetts); Strauss, supra note 14, at 96-97 (detailing specific components of an effective sexual harassment policy).

94 See, e.g., Lanpher, supra note 3, at 91 (“If schools are our laboratories, ... . one of the best ways to impact on this issue in the workplace would be to raise awareness in the classroom of what is acceptable conduct, including sexual conduct." (quoting Walteen G. Truely, Director, Project on Equal Education Rights (PEER), NOW Legal Defense and Education Fund)). 
conference, an apology to the victim, detention, suspension, expulsion, or referral to the police. ${ }^{95} \mathrm{~A}$ number of codes faced opposition for enumerating specific behaviors that are prohibited. One code lists the following as violations: "staring or leering with sexual overtones, [s]preading sexual gossip, [u]nwanted sexual comments, [p]ressure for sexual activity [and] any [u]nwanted contact of a sexual nature. ${ }^{96}$ Critics argue that behaviors such as gazing, staring, or gossip may not qualify as harassment and that the codes are overbroad. ${ }^{97}$ Others argue that these harassment codes may be unconstitutional because they punish private conversation. ${ }^{98}$

Other codes have not itemized forbidden behavior. ${ }^{99}$ Instead,

95 See, e.g., AMHERST-Pelham Regional High SchOOL, SEXUAL HARASSMENT Code (Mass. 1990) (on file with author).

${ }^{96} \mathrm{Id}$.

97 See John Leo, What Qualifies as Sexual Harassment?, U.S. NEWs \& WORLD REP., Aug. 13, 1990, at 17, 17. One critic was concerned about "[h]ow much gazing or leering would it take to be brought up on sexual-harassment charges." Id. He was also concerned that an ordinary, trivial comment from a student to a friend such as "I think Marcie and Allen have something going" would qualify as sexual harassment. Id. These two examples illustrate the problem of itemizing prohibited behavior. The context often defines whether behavior is sexual harassment. In the abstract, it is difficult to draw the line between acceptable and unacceptable behavior.

${ }^{98}$ No such case has been brought to date. In 1991, a University of Wisconsin rule prohibiting students from directing discriminatory epithets at particular individuals with intent to demean them and create a hostile educational environment was challenged. See UWM Post, Inc. v. Board of Regents, 774 F. Supp. 1163, 1165 (E.D. Wis. 1991). The district court held that the rule was overbroad and "unduly vague" and that the rule did not meet the requirements of the fighting words doctrine. See id. at 1177, 1180; cf. Chaplinsky v. New Hampshire, 315 U.S. 568, 572 (1942) (holding that fighting words are those "which by their very utterance inflict injury or tend to incite an immediate breach of the peace").

In regard to elementary and secondary schools, the Supreme Court has generally been reluctant to interfere with public school authorities' handling of school operations even when First Amendment problems have arisen. The Supreme Court has "recognized that the First Amendment rights of students in the public schools 'are not automatically coextensive with the rights of adults in other settings' and must be 'applied in light of the special characteristics of the school environment." Hazelwood Sch. Dist. v. Kuhlmeier, 484 U.S. 260, 266 (1988) (citations omitted) (quoting Bethel Sch. Dist. v. Fraser, 478 U.S. 675, 682 (1986) and Tinker v. Des Moines Indep. Community Sch. Dist., 393 U.S. 503, 506 (1969)). A student "may express his opinions, . . . if he does so without 'materially and substantially interfer[ing] with the requirements of appropriate discipline in the operation of the school' and without colliding with the rights of others." Tinker, 393 U.S. at 513 (alteration in original) (quoting Burnside v. Byars, 363 F.2d 744, 749 (5th Cir. 1966)). "The undoubted freedom to advocate unpopular and controversial views in schools and classrooms must be balanced against the society's countervailing interest in teaching students the boundaries of socially appropriate behavior.” Bethel Sch. Dist. No. 403 v. Fraser, 478 U.S. 675, 681 (1986).

${ }^{99}$ A Massachusetts school, Minuteman Tech, changed its sexual harassment code, 
the codes define harassment with a generalized statement similar to those adopted by the EEOC and OCR. ${ }^{100}$ One proposed policy states that "harassment includes unwelcome sexual advances and other verbal, visual, or physical conduct of a sexual nature that creates an intimidating, hostile, or offensive educational environment. ${ }^{n 101}$ Codes that define harassment broadly avoid the problems associated with sanctioning specific acts and instead, evaluate the behavior in the context of the situation. Although these codes are less likely to be attacked because they resemble Title VII and Title IX sexual harassment guidelines, opposition still exists. One common concern is that "[i]t's hard enough in a work environment, but in a high school where students are experimenting with behavior, knowing how far is too far-even if it's written-is still difficult." 102 The difference between friendly "kidding" or flirting and sexual harassment, though, is something students can learn-just as they learn math and science. ${ }^{103}$ Respect and proper conduct, especially proper sexual conduct, are ideas that can be incorporated into the school curriculum from kindergarten to twelfth grade. ${ }^{104}$ Indeed, as early as kindergarten, children are taught how to interact with each other. ${ }^{105}$ Moreover, sexual harassment is something

eliminating a list of prohibited behavior. Compare Minuteman Regional Vocational Technical Sch. Dist., Guidelines for Recognizing and Dealing with Sexual Harassment (Lexington, Mass., Nov. 6, 1980), reprinted in WHO's HURT AND WHO's LIABLE, supra note 34, at 27-28 (itemizing a list of actionable behaviors including "verbal comments, subtle pressure for sexual activity, leering, pinching, patting and other forms of unwanted touching, as well as rape and attempted rapen) with Minuteman Regional Vocational Technical Sch. Dist., Guidelines for Recognizing and Dealing with Sexual Harassment (Lexington, Mass., Feb. 20, 1991) [hereinafter 1991 Guidelines] (defining sexual harassment more generally as "[u]nwelcome sexual advances, requests for sexual favors and other verbal and physical conduct of a sexual nature.") (on file with author). The language was thought to be too broad. See Telephone Interview with Beverly W. Lydiard, Assistant Superintendent, Minuteman Regional Vocational Technical Sch. Dist. (Dec. 21, 1992).

${ }^{100}$ See supra text accompanying notes $28 \& 30$ for the EEOC and OCR guidelines on sexual harassment.

${ }^{101}$ Prime News: Teens Confront Problems of Sexual Harassment (CNN television broadcast, Mar. 29, 1992) (transcript on file with author).

${ }^{102} I d$.

103 Though it is a challenge, communication can bring about an understanding of the differences. See supra text accompanying notes 53-57 (explaining differences between flirting and sexual harassment).

${ }^{104}$ Placing a duty on the school to recognize and mediate sexual harassment problems encourages schools to implement programs on sexual harassment. See infra notes 240-50 and accompanying text.

${ }^{105}$ For example, children are taught how to share in school. 
students will have to understand if they plan to join the workforce. ${ }^{106}$

Some school systems are now recruiting experts to train school personnel to recognize and mediate sexual harassment problems ${ }^{107}$ and to conduct workshops on sexual harassment for students. ${ }^{108}$ Experts have found that there are a number of nonlitigious ways to resolve sexual harassment complaints. ${ }^{109}$ Nevertheless, no plan to prevent or handle sexual harassment cases will be effective unless "[t]he district's philosophy and policy on sexual harassment ... [ [has] the backing of the principal and ... [is] as well known as, for example, the policy on alcohol use."110

\section{B. The State Level}

Minnesota is a pioneer in state efforts to address the issue of academic sexual harassment. In 1982, it amended its antidiscrimination statute to include sexual harassment as "unwelcome sexual advances" or "physical conduct or communication of a sexual nature" that creates "an intimidating, hostile, or offensive ... environment" at work or in school. ${ }^{111}$ Minnesota also became the

106 In the workplace, discriminatory attitudes and behaviors are not tolerated because employers are held liable for co-worker harassment under Title VII. See, e.g., Intelkofer v. Turnage, 973 F.2d 773, 778 (9th Cir. 1992) (" $[$ T $]$ he employer must take some form of disciplinary action against the harassing co-worker in order to assure a workplace free of sexual harassment.").

107 Students have complained that teachers rarely take action on sexual harassment incidents. See Strauss, supra note 14, at 96 . Teachers are often themselves confused about sexual harassment and therefore do not intervene. See id. at 96-97.

108 See Shein, supra note 40, at 39; see also WHO's HURT AND WHO's LIABLE, supra note 34, at 35-75 (providing curriculum materials and activities such as questionnaires, role playing activities, and discussion exercises); Ruth Shalit, Romper Room, NEW REPUBLIC, Mar. 29, 1993, at 13, 13 (reporting on the experiences of an expert who conducted a sexual harassment workshop in an elementary school).

${ }^{109}$ One of the simplest and quickest ways to stop peer harassment is to write a letter to the harasser. See MORRIS ET AL., supra note 47, at 16-18 (providing a sample response to a harasser); 1991 Guidelines, supra note 99 (suggesting conferences and letters before formal action). The idea was developed in the early 1980s by Mary Rowe, then assistant to the president of the Massachusetts Institute of Technology. See Mary P. Rowe, Dealing With Sexual Harassment, HARV. BuS. REV., May-June 1981, at 42,43 . Nan Stein, a sex-equity specialist, recommends that the letter be handed to the harasser at school and in the presence of an adult. See Shein, supra note 40, at 39 . Harassment stops in $95 \%$ of the cases when a letter is written. See id. The success of this method is due, in part, to different perceptions of the same behavior that males and females hold. See supra notes 59-71 and accompanying text. Boys are often surprised to learn that they have offended the victim. See supra note 70.

110 Strauss, supra note 14 , at 97 .

111 MINN. STAT, ANN. § 363.01 .41 (West 1991). 
first and one of only two states to mandate that school boards adopt sexual harassment policies. ${ }^{112}$ It passed a law in 1989 requiring all schools to institute sexual harassment policies by the beginning of the 1991 school year. ${ }^{113}$ The policies must specify what constitutes sexual harassment as well as the reporting procedures and penalties for violations. ${ }^{114}$

In Minnesota, two cases involving student-to-student harassment in high school have arisen. In both cases, the Department of Human Rights ${ }^{115}$ ruled against the school district involved. In the first case, settled in 1991, the Duluth School District became the first in the nation to pay damages to a student who had been subjected to peer sexual harassment. ${ }^{116}$ The female student received a $\$ 15,000$ settlement after administrators failed to quickly paint over crude bathroom-wall graffiti about her. ${ }^{117}$ Later in 1991, the state ruled against the Chaska School District for failing to respond appropriately to harassment at its high school. ${ }^{118}$ School officials were accused of failing to take seriously a complaint by a female student against male students who were circulating a list of the twenty-five girls they found most desirable for sexual inter-

112 California is the other. See infra notes $121-24$ and accompanying text.

113 See MiNN. STAT. ANN. § 127.46 (West Supp. 1993).

114 State mandated policies alone, however, do not guarantee a school environment free from harassment. Two schools in Minnesota that had such policies in place had complaints filed against them by female students who claimed the school districts permitted environments of sexual harassment to flourish and interfere with their education. See infra notes 117-20 and accompanying text. The policies were developed and distributed but students and school personnel essentially ignored them. Measures, therefore, must be taken to ensure that such policies are taken seriously by students and staff. See supra note 110 and accompanying text.

115 The Department of Human Rights is a Minnesota state agency charged with investigating complaints and enforcing compliance with the sexual harassment legislation. See MINN. STAT. ANN. $\$ 363.05$ (West 1991) (defining the duties and powers of the commissioner of the department).

${ }^{116}$ See Gross, supra note 9, at B8.

117 See Lanpher, supra note 3 , at 90 . In addition to the cash settlement, the Duluth school system agreed to "post a revised sexual harassment policy in all schools, provide training for students and staff, and check bathrooms daily for graffiti." Id.

${ }^{118} \mathrm{See}$ id. 
course. ${ }^{119}$ The list included graphic descriptions of the girls' bodies. ${ }^{120}$

California is the only other state to pass legislation regarding school sexual harassment policies. ${ }^{121}$ A new law that went into effect in January, 1993, requires schools to adopt and distribute a written policy on sexual harassment. ${ }^{122}$ In addition, legislation permitting public school authorities to suspend or expel students in fourth through twelfth grade who sexually harass their classmates became effective January 1, 1993. ${ }^{123}$ Nonetheless, the California laws do not go as far as Minnesota's; they do not require discussion of sexual harassment to be included in the school curriculum and children in kindergarten and grades one through three are exempt from the law. ${ }^{124}$

On the state level, there are few alternatives for redressing sexual harassment other than relying on specific sexual harassment laws. Noncompensatory remedies may be available under criminal

119 The student's name was, in fact, on the list. See Lanpher, supra note 3, at 90; Sally Jessy, supra note 10, at 4-5. The other complaints involved a student who used a centerfold as a book cover, and lewd jokes and obscene pep rally skits at Chaska High School.

An interesting incident occurred when the local paper, the Chaska Herald, wrote a story about the sexual harassment problem at Chaska High School after the Human Rights Department ruled that the student raised valid points against the school. See Doug Grow, Lessons of Harassment Also Taught in Chaska, STAR TRIB. (St. Paul, Minn.), Oct. 13, 1991, at 1B; Sally Jessy, supra note 10, at 5. The story explained that the school's was negligent in its response to a computer-written list of the 25 most "fuckable" girls. The editor decided to use the obscenity that the list writers actually used to give readers a tiny sample of what the young women at Chaska High School were facing. It seems, though, that most people were more outraged that the editor wrote that one word than with the fact that young Chaska women had to face it everyday. Parents were irate. Ironically, "the Herald received far more angry calls for using the one objectionable word than the school ever had received for the frequent objectionable behavior." Grow, supra, at IB.

120 See Sally Jessy, supra note 10, at 4.

121 See CAL. EDUC. CODE § 212.5 (West Supp. 1993) (defining sexual harassment as "unwelcome sexual advances, requests for sexual favors, and other verbal, visual, or physical conduct of a sexual nature, made by someone from or in the work or educational setting").

122 See id. \$ 212.6.

123 See id. $\$ 48900.2$. Conduct determined to be sexual harassment under the California Education Code $\$ 212.5$ "must be considered by a reasonable person of the same gender as the victim to be sufficiently severe or pervasive to have a negative impact upon the individual's academic performance or to create an intimidating, hostile, or offensive educational environment." Id.

${ }^{124}$ In addition, there is no provision for training nor a requirement that the policies be written in English and Spanish. See Telephone Interview with Nan Stein, sex-equity specialist (Dec. 21, 1992). 
statutes. Whenever sexual harassment implies a threat of physical harm, sexual assault, or rape, the victim can press criminal charges against the harasser. ${ }^{125}$ Any actual sexual assault or rape is actionable. ${ }^{126}$ Although criminal sanctions have the advantage of the state paying for the prosecution, they may not be suitable for sexual harassment cases. First, only the egregious peer harassment cases are likely to be prosecuted. Many of the sexual harassment incidents do not rise to the level of harm necessary to make out a successful prosecutorial case. Second, the only potential compensation for the victim is the conviction of the harasser. The victim is not compensated for her personal losses. Finally, the broader issue of sexual harassment and school responsibility remains undisturbed.

Compensatory remedies may be available under traditional tort theories. A student might sue the harasser for assault, battery, or intentional infliction of emotional distress depending on the circumstances of the offensive behavior. ${ }^{127}$ The student may also

125 See, e.g., Model Penal Code $\S 211.1$ (1962) ("A person is guilty of assault if he: attempts to cause or purposely, knowingly or recklessly causes bodily injury to another; or ... attempts by physical menace to put another in fear of imminent serious bodily injury. Simple assault is a misdemeanor ...."). Threats of physical harm or retaliation may also involve forms of blackmail. See, e.g., id. § 212.5 ("A person is guilty of criminal coercion if, with purpose unlawfully to restrict another's freedom of action to his detriment, he threatens to: commit any criminal offense; or ... expose any secret tending to subject any person to hatred, contempt or ridicule $\ldots . . .7$.

${ }^{126}$ See, e.g., id. $\$ 213.4$ ("A person who has sexual contact with another not his spouse, or causes such other to have sexual contact with him, is guilty of sexual assault, a misdemeanor, if: he knows that the contact is offensive to the other person ...."); id. \$213.1 ("A male who has sexual intercourse with a female not his wife is guilty of rape if: he compels her to submit by force or by threat of imminent death, serious bodily injury, extreme pain or kidnapping, to be inflicted on anyone . . . ").

127 See RESTATEMENT (SECOND) OF TORTS $\$ 21$ (1965) (assault); id. § 18 (battery: offensive contact); id. $\S 46$ (outrageous conduct causing severe emotional distress). Tort suits, however, may not be an appropriate means to effectively redress peer sexual harassment. It may be difficult to prove these torts because the elements of the prima facie cases may not be present in peer sexual harassment incidents. An assault is any unlawful attempt "to cause a harmful or offensive contact" with the person of another or to cause an "apprehension of such a contact." Id. § 21. A battery occurs when such contact results. See id. $\S 13$. Thus, only some forms of peer sexual harassment can be categorized as an assault and/or battery because the harassing behavior must be in the form of a threatened or accomplished physical attack. See, e.g., Watson v. People Sec. Life Ins. Co., 588 A.2d 760, 767 (Md. 1991) ( $[\mathrm{E}]$ vidence supports finding a battery as well as an assault because [the male employee] placed his hands on [the female employee-plaintiff's] shoulders in both of his attempts to bite her on the breast."). To establish the tort of intentional infliction of emotional distress, the plaintiff must show extreme and outrageous conduct by the defendant causing severe emotional distress to the plaintiff. See RESTATEMENT 
have a claim against the school for intentional infliction of emotional distress. ${ }^{128}$

\section{THE FEDERAL STATUTORY AND REGULATORY SCHEME}

\section{A. Filing a Complaint Under Title IX}

Because most schools do not have sexual harassment policies and procedures and almost every state lacks legislation regarding sexual harassment in education, ${ }^{129}$ a student's recourse often exists only at the federal statutory level. ${ }^{130}$ Title IX of the Educa-

(SECOND) OF TORTS $\$ 46$ (1965). The common law has been slow to grant legal protection to a plaintiff's interest in freedom from emotional distress. The law is still in a stage of development and the boundaries of this tort are not yet determined. See, e.g., Foster v. Albertson, Inc., 835 P.2d 720, 728 (Mont. 1992) ("[W]e simply have not addressed a factual situation that would give rise to liability for the tort under the 'extreme and outrageous conduct' standard .....”). To qualify for liability, defendant's conduct must "go beyond all possible bounds of decency." RESTATEMENT (SECOND) OF TORTS $§ 46 \mathrm{cmt}$. d (1965); see also Aaron v. Werne, No. 65,060, 1991 Kan. LEXIS 57, at *10 (Kan. Mar. 1, 1991) (characterizing defendant's sexual remarks and gestures as "coarse," "crude," and "tasteless" but insufficient to constitute extreme and outrageous behavior). But see Bustamento v. Tucker, 607 So. 2d 532, 538-39 (La. 1992) (finding that the continuous nature of relatively "mild" harassment may have the effect of rendering such conduct tortious). Not only must defendant's conduct be extreme and outrageous, but plaintiff's emotional response must be severe. See Waddle v. Sparks, 414 S.E.2d 22, 28 (N.C. 1992) (finding "no forecast of any medical documentation of plaintiff's alleged 'severe emotional distress' nor any other forecast of evidence of 'severe and disabling' psychological problems").

In addition, schools have no incentive to take any measures to eliminate sexual harassment from the academic environment when the school is not directly affected by such a suit.

128 Tawnya Brawdy sued her school district in state court for "emotional distress" after the U.S. Department of Education found that the school had failed to protect her from sex discrimination. She collected $\$ 20,000$ in an out-of-court settlement. See Adler \& Rosenberg, supra note 11; Sally Jessy, supra note 10, at 2.

A suit against the school as opposed to the student-harasser for the intentional infliction of emotional distress involves the same proof problems. See supra note 127. Here, the proof problems may be more severe because the underlying injury is not committed by the defendant.

129 For a discussion of the two states that do have some type of school sexual harassment law, Minnesota and California, see supra notes 111-14, 121-24 and accompanying text.

${ }^{130}$ In addition to proceedings under Title IX, a student claiming peer sexual harassment might assert violations of her civil rights by her school under 42 U.S.C. $\$ 1983$. In pertinent part, that statute provides:

Every person who, under color of any statute, ordinance, regulation, custom or usage of any state . . . subjects, or causes to be subjected, any citizen of the United States or other person within the jurisdiction thereof 
tion Amendments Act of 1972 prohibits discrimination on the basis of sex in any educational program or activity receiving federal financial assistance. ${ }^{181}$ Enforcement of this prohibition occurs through the Department of Education's regulations. ${ }^{132}$ The Title IX regulations place certain affirmative obligations on the schools. In addition to requiring educational institutions to adopt and publish grievance procedures that provide for the "prompt and

to the deprivation of any rights, privileges, or immunities secured by the Constitution and laws, shall be liable to the party injured in an action at law, suit in equity or other proper proceeding for redress.

42 U.S.C. $\S 1983$ (1988). The crux of any $\S 1983$ action is a violation of a protected constitutional right. Here, the student needs to allege that she was deprived of her liberty interest which entitles her to be free from constant sexual harassment.

The likelihood of success for such a claim is uncertain. In Stoneking v. Bradford Area Sch. Dist., 882 F.2d 720 (3d Cir. 1989), the Third Circuit recognized the constitutional right of a student to be free from sexual abuse by school staff. See id. at 727 (' $[R]$ easonable officials would have understood the 'contours' of a student's right to bodily integrity, under the Due Process Clause, to encompass a student's right to be free from sexual assaults by his or her teachers."); see also Doe v. Taylor Indep. Sch. Dist., 975 F.2d 137, 143 (5th Cir. 1992) ("[B]odily integrity is necessarily compromised when a state actor sexually assaults a schoolchild ... and ... such misconduct implicates due process."). The court permitted the student-plaintiff to maintain a $\$ 1983$ claim based on the allegation that "defendants, with deliberate indifference to the consequences, established and maintained a policy, practice or custom which directly caused her constitutional harm." Stoneking, 882 F.2d at 725. Subsequently, the Third Circuit refused to extend this theory of $\$ 1983$ liability to a situation where the underlying violative acts were committed by students rather than state actors. See D.R. v. Middle Bucks Area Vocational Technical Sch., 972 F.2d 1364, 1376 (3d Cir. 1992), cert. denied, 113 S. Ct. 1045 (1993).

Basing much of its decision on DeShaney v. Winnebago County Dept. of Social Servs., 489 U.S. 189 (1989), the Third Circuit in D.R. also held that no special relationship exists between a student and her school to give rise to an affirmative constitutional duty on the part of state officials to protect students from serious harm. See D.R., 972 F.2d at 1368-73; see also DeShaney, 489 U.S. at $197\left({ }^{\text {"As a general }}\right.$ matter, ... a State's failure to protect an individual against private violence simply does not constitute a violation of the Due Process Clause."). But see Doe, 975 F.2d at 147 ("[P]ublic school officials have a duty to police the misconduct of their subordinates and to protect school children from hazards of which the school officials know or should know."). See generally Steven F. Huefner, Note, Affirmative Duties in the Public Schools After DeShaney, 90 ColUM. L. REV. 1940 (1990) (arguing that the DeShaney analysis can be applied to public schools, holding schools liable for failures to protect their students' safety). The Supreme Court refused to review the D.R. decision. See D.R. v. Middle Bucks Area Vocational Technical Sch., 113 S. Ct. 1045 (1993). Since the various theories of school liability under $\$ 1983$ have not been litigated in the federal courts, and the Supreme Court has not heard many of these issues, a $\$ 1983$ peer sexual harassment claim may be possible.

131 See supra note 19.

132 The main regulations are found in 34 C.F.R. $\$ 106.1-.71$ (1992), with certain procedural provisions found in 34 C.F.R. $\$ 100.6-11$ (1992) and 34 C.F.R. $\$ 101.2$ (1992). 
equitable resolution" of sex discrimination complaints, the regulations require schools to designate at least one employee to coordinate its efforts to comply with Title IX. ${ }^{133}$

Any person concerned about sexual harassment or any other form of discrimination ${ }^{134}$ may file a complaint with the school's internal grievance procedure and/or with the Department of Education. ${ }^{135}$ In cases of sexual harassment, complaints may be filed by students who allege they have personally been harassed, by groups of persons on behalf of a class of individual students who allegedly have been harassed, and by persons concerned that a recipient has failed to comply with the procedural requirements of the regulations. ${ }^{136}$ Therefore, complaints relating to sexual harassment will claim either procedural violations of the regulations, actual sexual harassment, or both.

Within the Department of Education, these complaints are reviewed by OCR. OCR investigates the alleged violations and makes a determination as to whether the recipient has failed to comply with Title IX. ${ }^{137}$ If no violation is found, the case will be closed. $^{138}$ If OCR determines that a Title IX violation has occurred, it will seek to remedy that violation through informal means, such as negotiations for voluntary compliance by the school. ${ }^{139}$ When voluntary compliance cannot be obtained, OCR and the Department of Education will require compliance with Title IX, generally through administrative proceedings. ${ }^{140}$ These proceed-

133 See 34 C.F.R. § 106.8-9 (1992).

134 Sexual harassment has been held to constitute a violation of Title IX even though there is no explicit reference to sexual harassment in either the statute or the regulations. See Alexander v. Yale Univ., 459 F. Supp. 1, 5 (D. Conn. 1977) (holding that a plaintiff who alleges sexual harassment "is within the class Title IX was designed to protect"), affd on other grounds, 631 F.2d 178, 185 (2d Cir. 1980) (agreeing with district court that a justiciable claim for relief under Title IX was presented). In 1981, OCR reaffirmed its jurisdiction over sexual harassment complaints under Title IX by issuing a policy memorandum adopting a definition of sexual harassment. See supra note $\mathbf{3 0}$ and accompanying text.

135 There are certain time restrictions on filing. See 34 C.F.R. $\$ 100.7$ (b) (1992) (180 days from the date of the alleged discrimination, unless extended by the responsible Department of Education official). Complainants, however, are not required to exhaust any internal grievance procedure before filing with the Department of Education.

${ }^{136}$ See id. $\$ 100.7(\mathrm{~b})-(\mathrm{c})$.

${ }^{137}$ See id. $\S 100.7(\mathrm{~d})(1)$.

${ }^{138}$ See id. $\$ 100.7(\mathrm{~d})(2)$.

${ }^{139}$ See id. $\S 100.7(\mathrm{~d})(1)$ (stating that "the matter will be resolved by informal means whenever possible").

${ }^{140}$ See id. § 100.8 . 
ings involve an administrative hearing, a review by the Department's Civil Rights Reviewing Authority, and a final review by the Secretary of Education. If the various administrative decisionmakers rule against the school, all federal financial assistance to that educational program may be terminated. ${ }^{141}$ In lieu of administrative proceedings, the Department of Education may refer the case to the Department of Justice to seek enforcement in the courts. ${ }^{142}$ It is important to note that the regulations do not provide any specific remedies for the complainant.

At age seven, Cheltzie Hentz is the youngest person and the first elementary school student in the United States to file a peer sexual harassment complaint with the Department of Education. ${ }^{143}$ She charged that the school district failed to monitor and discourage harassment directed toward her and other girls. It started in first grade when Cheltzie came home with stories about "naughty" language she had heard on the bus and how a first-grade boy called Cheltzie and another girl obscene names. Throughout the year there were other incidents, including repeated profanity and references to genitalia, that were directed at the girls on the bus. Often, Cheltzie would come home crying. Many days she did not want to get on the bus. Cheltzie concluded, "I guess that's just how boys are supposed to talk to girls, huh?"144

School officials contend that they undertook a number of steps to alleviate the problem. The boys were lectured and two were briefly suspended. Officials also asserted that sexual harassment education is part of the kindergarten through twelfth grade curriculum. ${ }^{145}$ Even Cheltzie's mother acknowledged that the situation on the bus improved significantly. Still, she is pursuing her complaint because she argues that even if the district has a

141 See id. \$ $100.8(\mathrm{a})$-(c).

142 See id. \$ 100.8(a).

143 See Adler \& Rosenberg, supra note 11; Rhonda Hillbery, Teasing on Bus Spurs a U.S. Probe, NEWSDAY (N.Y.), Dec. 6, 1992, at 19, 67; Rob Hotakainen, Student, 7, Claims Sex Harassment on Her Bus, STAR TRIB. (St. Paul, Minn.), Sept. 27, 1992, at 1A; Sally Jessy, supra note 10, at 1-2.

144 Hillbery, supra note 143 , at 19. Cheltzie's mother was appalled at the "idea that a seven-year old already has an idea of how one sex should treat another." Id. ${ }^{145}$ See id. 
policy on sexual harassment, it has failed to follow it. ${ }^{146}$ The complaint is currently under investigation.

\section{B. Sexual Harassment Caselaw Under Title IX}

Alternatively, a private civil suit may be brought against the school for violations of Title IX. In Cannon $v$. University of Chicago, ${ }^{147}$ the Supreme Court held that Title IX is enforceable through an implied private right of action. ${ }^{148}$ Although students have the right to sue under Title IX, in addition to the use of the complaint procedure through the Department of Education, few students have actually utilized the federal court system to adjudicate sexual harassment cases. ${ }^{149}$

Alexander $v$. Yale University ${ }^{150}$ was the first case to recognize that sexual harassment constitutes a violation of Title IX. Alexander established a student's claim for sexual harassment by a professor as cognizable under Title IX when the student has suffered loss of tangible educational benefits. In Alexander, three students alleged personal experiences of sexual harassment. Two of the students alleged harm as a result of a poisoned educational environ-

${ }^{146}$ Even if the school did take action in accordance with its policy, the Department of Education may find that the action was not taken promptly.

Cheltzie's mother also wants the district to implement a comprehensive program on sexual harassment for both students and staff and to place adults or video monitors on school buses. The Superintendent protested that the video cameras would cost a "prohibitive $\$ 500,000$." See id. at 67 . The plan was also criticized for its "Big Brother" potential with a camera on every bus. See id. In light of the cost and privacy considerations, the sexual harassment program may be the best solution to reduce future harassing conduct.

147441 U.S. 677 (1979).

148 Id. at 717.

149 American society only recently recognized sexual harassment as a legitimate issue, and subsequently, a cognizable legal claim. Young women are now learning that the harassing conduct they have been subjected to in school has a name-peer sexual harassment. Furthermore, students are generally unaware of Title IX and the rights guaranteed under the statute. As awareness of both sexual harassment and the remedial power of Title IX increases, litigation in the federal courts can be expected to escalate. 1980).

150459 F. Supp. 1 (D. Conn. 1977), affd on other grounds, 631 F.2d 178 (2d Cir. 
ment. ${ }^{151}$ Their claims were dismissed. Pamela Price, the only plaintiff to survive motions to dismiss, asserted that she received a poor grade in a course in her major field of study because she rejected the sexual demands of her professor. The district court held that "academic advancement conditioned upon submission to sexual demands constitutes sex discrimination in education" but determined that the plaintiff failed to prove her claim. ${ }^{152}$ On appeal, the Second Circuit affirmed all the dismissals except Price's. ${ }^{153}$ It did not address, however, one of the district court's bases for dismissal-that creation of a discriminatory environment, unaccompanied by the loss of tangible benefits, does not constitute sexual harassment. ${ }^{154}$ Rather, the Second Circuit held that the graduation of the plaintiffs who had asserted such claims rendered them moot. ${ }^{155}$ Thus, the Second Circuit only recognized quid pro quo sexual harassment as a violation of Title IX. ${ }^{156}$

Moire v. Temple University School of Medicine ${ }^{157}$ was the second federal decision on sexual harassment under Title IX. The district court permitted the student's claim for sexual harassment based solely on environmental harm, though it found no merit in the particular complaint before the court. ${ }^{158}$ To date, Moire is the only federal decision recognizing hostile-environment sexual harassment in a purely educational context.

151 See Alexander, 459 F. Supp. at 2-5. One co-plaintiff alleged harm on learning that another female student had been the victim of direct sexual harassment by a male university employee. See id. at 3 . She claimed she was deprived of "the tranquil atmosphere necessary to her pursuit of a liberal education." Alexander, $631 \mathrm{~F} .2 \mathrm{~d}$ at 182. She and another co-plaintiff also alleged that the university lacked an effective complaint network. See Alexander, 459 F. Supp. at 2-3.

152 Id. at 4.

153 See Alexander, 631 F.2d at 185.

154 See Alexander, 459 F. Supp. at 3 ("No judicial enforcement of Title IX could properly extend to such imponderables as atmosphere or vicariously experienced wrong, and the claims just mentioned are untenable on their face.").

155 See Alexander, 631 F.2d at 184.

${ }^{156}$ For a definition of quid pro quo harassment, see supra note 31 and accompanying text.

157613 F. Supp. 1360 (E.D. Pa. 1985), affd, 800 F.2d 1136 (3d Cir. 1986). In Moire, a female medical student challenged her psychiatric clerkship grade, alleging that the university and her supervisor at the private clinic conspired against her and failed her because of her sex. She also charged that her supervisor subjected her to sexual harassment and that his colleagues and the university faculty members sought to protect him. See id. at 1362.

${ }^{158}$ See id. at 1366-70. The district court specifically identified the Title IX issue as being "whether [the] plaintiff because of her sex was in a harassing or abusive environment ...." Id. at 1367. Ultimately, the court found no credible evidence to support her allegations of sexual harassment. See id. at 1370. 
The only other federal appellate decision in this area was Lipsett v. University of Puerto Rico. ${ }^{159}$ Annabelle Lipsett, plaintiff-appellant, was a surgery resident at the University of Puerto Rico School of Medicine. ${ }^{160}$ Ms. Lipsett alleged that she was sexually harassed while in the medical program and that she was dismissed from the program because of her sex. ${ }^{161}$ There were many instances of sexual discrimination cited: the chief resident warned the plaintiff that surgery was a "male preserve not hospitable to women"; ${ }^{162}$ a second chief resident was very explicit about his contempt for women residents; ${ }^{163}$ the plaintiff was repeatedly warned that some of the male doctors wanted her and the other women eliminated from the program. ${ }^{164}$

Other males in the residency program offered to protect her if she had sex with them, made repeated sexual remarks about her body, frequently came in close physical contact with her, made repeated sexual advances, and became unfriendly and hostile when she refused to succumb to sexual demands. ${ }^{165}$ The men also posted a sexually explicit drawing of the plaintiff, a list containing sexually charged nicknames for the plaintiff and other female residents, and Playboy centerfolds in an area where all the residents congregated for meals and meetings. ${ }^{166}$ Other doctors prevented her from operating and refused to assign her appropriate tasks. ${ }^{167}$

Although she complained to supervisors about the sexual harassment, her complaints were dismissed and no action was taken. No one in authority conducted an investigation nor reprimanded or punished the harassers. In fact, Ms. Lipsett was dismissed for behavioral problems. ${ }^{168}$

The First Circuit held that Ms. Lipsett made out a prima facie case of quid pro quo and hostile work environment sexual harassment. The court explicitly extended the "Title VII standard for proving discriminatory treatment ... to [the plaintiff's] claims of sex discrimination arising under Title IX" because the plaintiff was

\footnotetext{
${ }^{159} 864$ F.2d 881 (1st Cir. 1988).

160 See id. at 884.

161 See id.

162 Id. at 887.

163 See id.

${ }^{164}$ See id. at 887-88.

165 See id. at 888.

${ }^{166}$ See id.

167 See id. at 887-89.

${ }^{168}$ See id. at 892.
} 
both an employee and a student in the program. ${ }^{169}$ Thus, the First Circuit only established that sex discrimination standards developed under Title VII apply to employment-related claims under Title IX. The court limited its discussion on discriminatory treatment to a "mixed employment-training context," never addressing the situation where the victim was solely a student. ${ }^{170}$

The preceding three cases are the only reported federal cases to adjudge a claim of sexual harassment under Title IX. This dearth of Title IX cases may soon change as a result of a relatively recent decision by the Supreme Court. In February 1992, the Supreme Court ruled in Franklin v. Gwinnett County Public Schools ${ }^{171}$ that monetary damages are available for a private action brought to enforce Title IX. ${ }^{172}$ The decision overturned a ruling by a federal appeals court in Atlanta that had dismissed a Title IX suit against the Georgia school district. ${ }^{178}$ The case was brought by a former female high school student who charged that school officials had failed to stop a teacher from sexually harassing and abusing her. ${ }^{174}$ In the past, students opted to file complaints with the Department of Education because the cost of pursuing the complaint is underwritten by the government. There is virtually no cost to the complainant because OCR investigates the complaints and seeks remedies for violations. ${ }^{175}$ At the same time, the case is controlled by OCR and the complainant's agreement is not a necessary part of any settlement agreement between OCR and the school. Moreover, complainants are limited in the remedies they can receive through the OCR administrative process. OCR can only

${ }^{169} I d$. at 897 . As a resident in the program, Ms. Lipsêtt was receiving both training and a salary. See $i d$.

$170 \mathrm{Id}$.

171112 S. Ct. 1028 (1992).

172 See id. at 1038.

173 See Franklin v. Gwinnett County Pub. Sch., 911 F.2d 617, 622 (11th Cir. 1990), rev'd, 112 S. Ct 1028, 1038 (1992).

${ }^{174}$ Christine Franklin claimed Andrew Hill, a sports coach and teacher, started harassing her in 1986, when she was a high school sophomore. She claimed he asked her about her sexual experiences with her boyfriend and whether she would have sex with an older man, forcibly kissed her on the mouth in the school parking lot, and called her at home to ask her out. Three times in her junior year, Franklin alleged, Hill interrupted a class to ask that the teacher excuse Franklin, then took her to a private office where he had sex with her. Franklin said the school teachers and administrators were aware of Hill's harassment of her and other female students but did nothing to halt it and discouraged her from pressing charges against Hill. See Franklin, 112 S. Ct. at 1031.

175 See supra notes $137-42$ and accompanying text (explaining the duties of $O C R$ ). 
require compliance with Title IX. ${ }^{176}$ This entails merely structural changes-such as prohibiting particular conduct, requiring schools to establish grievance procedures, and dismissing the offenders-to correct past problems and prevent them in the future. ${ }^{177}$ Before Franklin, similar equitable relief was also available to students who filed private Title IX suits in federal court. ${ }^{178}$ After Franklin, student victims of sexual harassment can add suits for personal compensation to their Title IX legal arsenal. ${ }^{179}$

${ }^{176}$ See 34 C.F.R. § 100.8(a) (1992). Although OCR's authority to cut off federal funding to schools that refuse to comply may serve the goal of terminating federal support of discrimination, it does little to remedy the harm of sex discrimination. As one commentator has noted, "[v]ictims are primarily interested in compensation for the harm done to them, not in fund-termination. ... . [T]he fund-termination remedy offers little consolation to discrimination victims." Pamela W. Kernie, Comment, Protecting Individuals from Sex Discrimination: Compensatory Relief Under Title IX of the Education Amendments of 1972, 67 WASH. L. REV. 155, 166 (1992) (footnotes omitted). The OCR remedial scheme does not compensate victims for their losses. "Indeed, the fund-termination remedy, if applied, might actually prove detrimental to the very people Title IX is designed to protect: if an educational program's funds are terminated, future participants in the program will be denied the benefits of muchneeded federal assistance." Id. at 165; see also supra part I.C. (discussing victims' losses in terms of the negative effects of peer sexual harassment on a student's education). Furthermore, the OCR regulations provide no penalty to deter future harassment from occurring again.

${ }^{177}$ In the Franklin case, the female student had filed a complaint with OCR after the school district closed its investigation. After investigating the matter for several months, OCR concluded that the school district had violated the student's rights, but because of Hill's resignation and the implementation of a school grievance procedure, the district had come into compliance with Title IX. See Franklin, 112 S. Ct. at 1031 n.3.

178 In Franklin, prospective relief would afford the student no remedy because the teacher had resigned and the student had graduated. See Franklin, 112 S. Ct. at 1038. Administrative action "help[s] other similarly-situated students" but "would leave [the victim] remediless." Id.

Similarly, employees' remedies under Title VII were inadequate until relatively recently. Until 1991, an employee who brought a hostile work environment claim under Title VII could only seek reinstatement, backpay, and attorncy's fees. See King v. Board of Regents, 898 F.2d 533, 537 (7th Cir. 1990). Reinstatement is frequently not desired by the employee: a vindicated employee is often reluctant to return to the work environment because of fear of ostracism and backlash from other employees and supervisory personnel. Recovery of backpay is also extremely limited in cases of sexual harassment, as there is often no loss of tangible job benefits: a victim who must work for economic reasons may mitigate damages attributable to backpay by quickly finding other employment. Furthermore, these remedies are insufficiently threatening to pressure employers to modernize their policies. In November 1991, however, the Civil Rights Act was signed into law providing for compensatory and punitive damages under Title VII. See Civil Rights Act of 1991, Pub. L. No. 102-166, 105 Stat. 1099 (to be codified at 42 U.S.C. \$ 1981a). It gives Title VII plaintiffs the right to collect damages for their harms and encourages employers to take steps to deter potential harassers.

${ }_{179}$ OCR's authority, however, has not changed. It cannot require educational 


\section{Peer harassment Violates Title IX}

To date, no court has extended Title IX protection to student-tostudent harassment victims at any level of education. In fact, with the exception of the Lipsett case, ${ }^{180}$ there have been no reported Title IX cases arising out of a peer harassment claim. ${ }^{181}$ The applicability, however, of the Lipsett decision to peer harassment in elementary and secondary schools is limited because the harassment there occurred in an institution of higher education and in a combined educational/employment context. Because no court has explicitly dealt with the issue of peer sexual harassment in primary and secondary school, future student claimants will initially need to demonstrate that unabated peer sexual harassment is a violation of Title IX. An inquiry into this issue begins with an examination of the statutory language and regulations of Title IX. ${ }^{182}$ In interpreting Title IX, the only guidance provided by the Supreme Court is that it must be accorded "a sweep as broad as its language." 183

Title IX specifically states, in relevant part: "No person in the United States shall, on the basis of sex, be excluded from participation in, be denied the benefits of, or be subjected to discrimination under any educational program or activity receiving Federal financial assistance ...."184 The statute does not differentiate between the level of education of the victim nor between employee

institutions to compensate individuals. Victims of sexual harassment can only be compensated by bringing suit themselves.

${ }^{180} 864$ F.2d 881 (1st Cir. 1988).

181 In Lipsett, the plaintiff was harassed by the residents as well as her superior. The residents were both her co-workers and classmates. See supra notes 159-70 and accompanying text (relating the facts of the case).

${ }^{182}$ It is also helpful to analyze Title IX's legislative history. Title IX was enacted in response to a growing concern about the problem of sex discrimination in education. See 118 CoNG. REC. 5804-15 (1972); id. at 5804 ("[B]ecause education provides access to jobs and financial security, discrimination here is doubly destructive for women.") (statement of Sen. Bayh). Title IX was designed to promote two related, but somewhat different, objectives. First, Congress wanted to prevent distribution of federal funds to educational institutions engaging in sex discrimination. See 117 CONG. REC. 39,252 (1971) ("Millions of women pay taxes into the Federal treasury and we collectively resent that these funds should be used for the support of institutions [that discriminate].") (statement of Rep. Mink). Second, Congress wanted to provide individuals with protection against such practices. See 118 CONG. REC. 5806-07 (1972) (" [Title IX] is a strong and comprehensive measure which I believe is needed if we are to provide women with solid legal protection as they seek education and training for later careers ....") (statement of Sen. Bayh, sponsor of the Senate bill).

183 North Haven Bd. of Educ. v. Bell, 456 U.S. 512, 521 (1982).

18420 U.S.C. $\S 1681$ (a) (1988). 
and student victims. Any elementary or secondary school student discriminated against because of sex should have a claim against his or her school.

The question then becomes whether victims of peer sexual harassment are "excluded from participation," "denied ... benefits," or "subjected to discrimination" in school. Peer sexual harassment is a form of sex discrimination because it is almost always directed against one gender. When peer sexual harassment is not addressed, ${ }^{185}$ it "emerges as a critical variable influencing events and outcomes" in a student's life. ${ }^{186}$ Young women who have experienced peer sexual harassment report that it interferes with their psychological, social, and physical well-being. ${ }^{187}$ These responses negatively affect their learning, attendance, course choices, and grades. Peer sexual harassment can impair academic progress and inhibit the attainment of goals so that a young woman is effectively limited in her educational and career opportunities and, consequently, economic potential. For instance, a low grade may make her ineligible for other classes or educational programs which may provide necessary skills or exposure to spark interest in particular career tracks. The victim herself may voluntarily withdraw from a course, field of study, or school to cope with the harassment. ${ }^{188}$ Peer sexual harassment plays an instrumental role in keeping females out of nontraditional fields of study or employment, such as skilled trades, science, and engineering. ${ }^{189}$

${ }^{185}$ See supra notes 50-73 and accompanying text (explaining why peer sexual harassment is often not addressed).

${ }^{186}$ Karen Bogart \& Nan Stein, Breaking the Silence: Sexual Harassment in Education, 64 PEABODY J. EDUC. 146, 147 (1989).

${ }^{187}$ For a discussion of the effects of peer sexual harassment, see supra part I.C.

188 See supra text accompanying note 12; Sally Jessy, supra note 10, at 2.

189 One young woman who graduated from a vocational high school gave the following testimony before the Commerce and Labor Committee of the Massachusetts Legislature:

Quite often [females] never enroll in vocational schools because they are aware of the behavior they can expect from their male peers.

The threat of sexual harassment stands in the way of both male and female students who wish to participate in vocational education programs which are not typical for their sex.

... Frequently such non-traditional students drop out of their programs in order to escape from uncomfortable working and learning conditions. Who's HURT AND WHO's LIABLE, supra note 34, at 4.

Of course, peer harassment may not be the only factor discouraging females from pursuing a nontraditional career. Other factors, such as sexual harassment from teachers and administrators, lack of role models, family choices, and societal stereotypes and myths, also may influence a young woman's choice of study. 
At the same time, males continue to participate in the educational opportunities and enjoy the benefits of their schools without the interferences that confront their female classmates. In general, young men do not face the dilemma of how to find a way to avoid peer sexual harassment without a disruption in their educational environment. Although the actual harassment is not perpetrated by school officials, a school that responds to peer sexual harassment by overlooking or ignoring such behavior effectively condones the harassment and permits that which is specifically prohibited by Title IX.

The Department of Education's regulations govern the implementation and enforcement of Title IX.190 These regulations distinguish education programs from employment programs, but prohibit discrimination in both. ${ }^{191}$ The section relating to education programs and activities provides that "no person shall, on the basis of sex, be excluded from participation in, be denied the benefits of, or be subjected to discrimination under any academic, extracurricular, research, occupational training, or other education program or activity operated by a recipient which receives or benefits from Federal financial assistance." 192 Although Title IX gives no further explanation of the meaning of to "be excluded from participation in, be denied the benefits of, or be subjected to discrimination," the Department of Education regulations provide a partial answer:

Except as provided in this subpart, in providing any aid, benefit, or service to a student, a recipient shall not, on the basis of sex:

(1) Treat one person differently from another in determining whether such person satisfies any requirement or condition for the provision of such aid, benefit, or service;

(2) Provide different aid, benefits, or services or provide aid, benefits, or services in a different manner;

(3) Deny any person any such aid, benefit, or service;

(4) Subject any person to separate or different rules of behavior, sanctions, or other treatment. ${ }^{193}$

If a school investigates most student complaints, but not those involving peer sexual harassment, that school, at a minimum,

190 See supra note 132 and accompanying text.

191 Compare 34 C.F.R. \$ 106.31-.42 (1992) (prohibiting sex discrimination in education programs and activities) with id. $\$ 106.51-.61$ (prohibiting sex discrimination in employment in education programs and activities).

${ }^{192} I d$. $\$ 106.31(\mathrm{a})$.

${ }^{193} I d . \S 106.31(\mathrm{~b})(1)-(\mathrm{b})(4)$. 
violates sections (1) to (4) of the Department of Education regulations. ${ }^{194}$ A school denies services to its female students, and provides services in a different manner, if it fails to investigate and punish peer sexual harassment as swiftly and thoroughly as it does other misconduct such as fighting, swearing, and cheating. Not punishing student harassers, or punishing them very lightly, indicates that a school treats these students with "different rules of behavior [and] sanctions." 195 Indeed, the school is applying differential treatment on the basis of sex.

\section{Peer SeXual Harassment and THE HOSTILE ENVIRONMENT THEORY}

\section{A. Applying Title VII to Title IX}

If peer sexual harassment is allowed to occur, it will disrupt the right to equal education under Title IX by creating an intimidating, hostile, or offensive environment. Therefore, peer sexual harassment is what the federal courts deem hostile-environment sexual harassment. ${ }^{196}$ The only federal court to recognize the hostile environment theory in a purely educational context described the environment as one "where multiple incidents of offensive conduct lead to an environment violative of a victim's . . . rights." 197

The creation or maintenance of an environment hostile to females should be proscribed under Title IX as it is currently proscribed under Title VII. ${ }^{198}$ Hostile-environment harassment, like quid pro quo harassment, is as reprehensible in the academic context as in the employment context. In both situations, the victim is powerless to stop the harassment. ${ }^{199}$ Such behavior demeans

194 See id.; see also Terry N. Steinberg, Rape on College Campuses: Reform Through Title IX, 18 J.C. \& U.L. 39, 54 (1991) (arguing that a university that fails to investigate and punish date rape on campus violates sections (1) to (4) of the regulations); supra text accompanying note 193 (quoting the text of the relevant regulations). Date rape, like peer sexual harassment, is a form of sex discrimination because it is almost always directed against females. Steinberg's argument can easily be analogized to hold schools liable for ignoring or trivializing peer sexual harassment.

195 34 C.F.R. § 106.31(b)(4).

196 See supra notes 28,32 and accompanying text (defining hostile-environment harassment).

${ }^{197}$ Moire v. Temple Univ. Sch. of Medicine, 613 F. Supp. 1360, 1366 (E.D. Pa. 1985), affd, 800 F.2d 1136 (3d Cir. 1986).

198 See Meritor Sav. Bank v. Vinson, 477 U.S. 57, 73 (1986) (holding "a claim of 'hostile environment' sexual discrimination to be actionable under Title VII").

199 See supra notes 59-62 and accompanying text (explaining the power-differential 
and often unnerves the victim in both academia and the workplace. ${ }^{200}$ Regardless of the context, the culture of sexual harassment is maintained by silence. Victims may be too intimidated or embarrassed to report the behavior and often blame themselves. Observers may misinterpret, ignore, or condone such behavior because they lack guidelines for addressing it. Furthermore, sexual harassment in either context appears related to the same factors: gender differences in interpersonal perception and communication and societal sex-role stereotyping. ${ }^{201}$

In fact, the recognition of a hostile environment claim in an elementary or secondary school may be even more important under Title IX than under Title VII. As one commentator has noted:

[T] he importance and function of environment is different in academia than in the workplace. Even if one were to concede ... that an offensive harassing environment, by itself, does not necessarily affect employee productivity, the same is certainly not true with regard to education. A nondiscriminatory environment is essential to maximum intellectual growth and is therefore an integral part of the educational benefits that a student receives. A sexually abusive environment inhibits, if not prevents, the harassed student from developing her full intellectual potential and receiving the most from the academic program. Any diminution or deprivation of such an academic benefit on the basis of sex violates Title IX. ${ }^{202}$

Additionally, elementary and secondary school students' mobility is more restricted than that of an employee. Elementary and secondary school students are essentially captives in their educational environments. Although employees may face practical difficulties in moving from one workplace environment to another, ${ }^{203}$ their choice to be employed at any particular place is largely voluntary.

theory).

200 The form of behavior is often the same in both contexts. Compare supra notes 45-49 (female students often have sexual remarks, touching, and gestures directed at them by male classmates) with Katz v. Dole, 709 F.2d 251, 253-54 (4th Cir. 1983) (coworkers inflicted sexual slurs, insults, and propositions on female air traffic controller) and Hall v. Gus Constr. Co., 842 F.2d 1010, 1012 (8th Cir. 1988) (male crew members incessantly referred to the female traffic controllers at road sites as "fucking flag girls," requested that they engage in oral sex with them, rubbed their hands on the women's thighs, and grabbed at their breasts).

${ }^{201}$ See supra notes $59-73$ and accompanying text.

202 Schneider, supra note 13, at 551 (footnotes omitted).

203 Such practical difficulties include the availability of a different job with the same pay scale and responsibility level as the original job, and familial or social ties to a geographic area. 
Education, on the other hand, is mandatory. ${ }^{204}$ Indeed, most children are required to attend a particular district public school. ${ }^{205}$ Transferring from one public school to another is often difficult. ${ }^{206}$ Furthermore, transferring to a private school is often not a viable option because of the costs of such an education. ${ }^{207}$ Moreover, the mere age of schoolchildren dictates that they have less independence than adult employees and, thus, virtually no independent choice in their educational environment.

Nevertheless, harassers in either environment should be held accountable for their behavior. If females will not accept an abusive environment in the workplace anymore, why should they do so at school? The classroom is the precursor to the workplace. The same girls and boys who are now classmates will face each other again as co-workers. "If no one teaches boys that harassment is wrong, why should they stop harassing women as adults?"208 Moreover, adolescent girls deserve the same respect as adult women. Male conduct that poisons an environment-whether it be work-related or academic-with hostility and abuse towards females is a serious problem regardless of the age of the harassers or victims; such conduct negatively affects both women's educational and employment productivity and opportunities. Consequently, a definition of sexual harassment under Title IX must encompass the creation of an offensive, hostile, or abusive environment similar to that recognized under Title VII.

This Comment proposes that the Title VII standards for proving hostile work environment sexual harassment should apply as well to claims of hostile academic environment sexual harassment under Title IX. It seems most advantageous to adopt Title VII standards

${ }^{204}$ See, e.g., CAL. EDUC. CODE $§ 48200$ (West 1992); 24 PA. CONS. STAT. § 13-1326 (1991); TEX. EDUC. CODE ANN. § 21.032 (West 1992). But see Wisconsin v. Yoder, 406 U.S. 205, 234-36 (1972) (invalidating Wisconsin's refusal to exempt 14-and 15-year-old Amish students from the requirement of attending school until the age of 16).

205 See, e.g., CAL. EduC. CODE $\$ 48200$ (West 1992) ("Each person ... . shall attend the ... school ... in which the residency of either parent or legal guardian is located.").

${ }^{206}$ In California, for example, the transfer will only occur if the two boards concerned "agree that it is for the best educational and health interest of the child." Id. $\$ 46609$.

207 See generally The Handbook OF PRIVATE Schools (73d ed. 1992) (providing a short description, including the cost of tuition, of each private primary and secondary school in the United States and foreign countries).

208 Adler \& Rosenberg, supra note 11, at 77 (quoting Leslie Wolfe of the Center for Women Policy Studies). 
as a starting point for building a prima facie case in view of the paucity of Title IX decisions. Reference to Title VII is helpful because courts adjudicating sexual harassment cases in the employment context have already encountered some of the same issues that arise in the Title IX context.

\section{B. A Proposal to Establish a Prima Facie Case of Sexual Harassment Creating a Hostile Educational Environment Under Title IX}

This Comment proposes that to prevail in a Title IX hostileenvironment sexual harassment action holding an educational institution liable, a plaintiff must assert and prove that: (1) the student was a member of a protected class; (2) the student was subjected to unwelcome sexual harassment; (3) the harassment was prompted simply because of the student's gender; (4) the charged sexual harassment was sufficiently severe or pervasive to create an intimidating, hostile, or offensive educational environment; and (5) an official representing the educational institution knew or should have known of the harassment and failed to take prompt and appropriate remedial action.

The preceding proposal incorporates portions of standards followed by differing circuit courts in the employment context. ${ }^{209}$ Although this proposal speaks generally to the hostile academic environment, regardless of academic level or relationship of harasser to victim, it squarely addresses the problem of peer sexual harassment in elementary and secondary schools. ${ }^{210}$ In order to prevail in the proposed hostile educational environment claim, the student-plaintiff will have the burden of proving all five elements.

The first element simply requires that the student belong to a protected group. In a sexual harassment case, the requirement is satisfied if there is a stipulation between the parties that the plaintiff is either a man or a woman. ${ }^{211}$ This element is needed to prove

209 See, e.g., Jordan v. Clark, 847 F.2d 1368, $1373-75$ (9th Cir. 1988) (detailing the "abusive environment" requirement), cert. denied, 488 U.S. 1006 (1989); Rabidue v. Osceola Refining Co., 805 F.2d 611, 619-20 (6th Cir. 1986) (discussing all five parts of the sexual harassment test), cert. denied, 481 U.S. 1041 (1987); Henson v. City of Dundee, 682 F.2d 897, 903-05 (11th Cir. 1982) (similar discussion).

210 Though this proposal reaches peer sexual harassment and professor-student sexual harassment at the university level, the issues raised by imposing such liability are beyond the scope of this Comment.

211 See, e.g., Henson, 682 F.2d at 903 (explaining that a stipulation satisfies the first requirement); Trotta v. Mobile Oil Corp., 788 F. Supp. 1336, 1348 (S.D.N.Y. 1992) 
that the harasser is of the opposite sex and thus the victim is within the protected class under Title IX.

Second, the student must be the subject of unwelcome sexual harassment. The EEOC Guidelines are helpful in defining the type of conduct that may constitute sexual harassment: unwelcome sexual advances, requests for sexual favors, and other verbal or physical conduct of a sexual nature. ${ }^{212}$ In fact, the court in Moire noted that the EEOC Guidelines "seem equally applicable to Title IX."213 Any definition, however, must be broad enough to encompass the diversified behavior generated by peer sexual harassment ranging from pinching and epithets to overt sexual conduct. $^{214}$ Thus, the offensive conduct should not be limited to that which has explicit sexual overtones. In fact, as one court has noted, " $\mathrm{t}]$ he Supreme Court in no way limited [the hostile-environment sexual harassment claim under Title VII] to intimidation or ridicule of an explicitly sexual nature. ${ }^{215}$

In order to constitute harassment, the "conduct must be unwelcome in the sense that the [student] did not solicit or incite it, and in the sense that the [student] regarded the conduct as undesirable or offensive. ${ }^{216}$ The only Supreme Court decision to date on hostile-environment harassment leaves open the question of whose perspective should be used in assessing unwelcomeness in the workplace context. ${ }^{217}$ The First Circuit has suggested that

(same analysis).

212 See supra text accompanying note 28 (listing conduct constituting sexual harassment under the EEOC Guidelines).

213 Moire v. Temple Univ. Sch. of Medicine, 613 F. Supp. 1360, 1366 n.2 (E.D. Pa. 1985), affd, 800 F.2d 1136 (3d Cir. 1986).

214 See supra notes $37,45-49$ and accompanying text (describing the types of harassment a young woman in elementary or secondary school faces).

${ }^{215}$ Andrews v. City of Phila., 895 F.2d 1469, 1485 (3d Cir. 1990). In the employment context, many of the circuit courts adopt the EEOC Guidelines and require that the alleged harassment take the form of sexual advances, requests for sexual favors, or other verbal or physical conduct of a sexual nature. See Jones v. Flagship Int'], 793 F.2d 714, 719-20 (5th Cir. 1986) (requiring that "[t]he harassment complained of was based upon sex"), cert. denied, 479 U.S. 1065 (1987); Henson, 682 F.2d at 903-05 (similar analysis); see also 29 C.F.R. \$ 1604.11(a) (1992) (EEOC Guidelines) (similar analysis). Some courts, however, hold that the alleged conduct need not be explicitly sexual. See Andrews, $895 \mathrm{~F} .2 \mathrm{~d}$ at 1485 ( ${ }^{\text {"[TT }}$ he pervasive use of derogatory and insulting terms relating to women generally and addressed to female employees personally may serve as evidence of a hostile environment. "); Hall v. Gus Constr. Co., 842 F.2d 1010, 1014 (8th Cir. 1988) ("[N]one of our previous cases hold that the offensive conduct must have explicit sexual overtones.").

216 Henson, 682 F.2d at 903.

217 See Meritor Sav. Bank v. Vinson, 477 U.S. 57, 68 (1986); see also Lipsett v. 
both the man and the woman's perspective should be taken into account. ${ }^{218}$ One commentator has recommended that welcomeness should be determined "using the plaintiff's perspective, but imposing an objective requirement on the plaintiff to let the defendant know that his or her conduct is unwelcome." 219 Another commentator has proposed that the defendant be required to prove that the plaintiff welcomed the defendant's specific advances. 220 Frequently, victims of sexual harassment remain silent because they may be too intimidated, frightened, or embarrassed to stop the behavior or they just blame themselves. Placing the duty on the plaintiff to make an overt gesture or remark of unwelcomeness is inconsonant with the dynamics of sexual harassment. On the other hand, assessing unwelcomeness from the perspective of the plaintiff ignores the context in which both participants behaved. If a female openly flirts and tells sexually explicit jokes, it is unfair to protect her from males who give her the same treatment. Furthermore, use of such a rule does not encourage females to express their disapproval of harassing behavior. Females must be proactive to effect change. If males are to learn what behavior is harassing, females must continue to tell them when their behavior is unacceptable and why. How the victim confronts the harasser depends upon the situation. The suggestion that the defendant prove that his behavior is welcome forces the defendant to evaluate the context of the situation. He will not act unless he has good reason to believe his conduct is not unwelcome. The standard is harsher on the defendant yet makes the plaintiff account for her own behavior because the defendant can use her overt behavior, if unreasonable, to refute her claim.

The third element requires the student to prove that but for the fact of her gender, she would not have been the object of harassment. ${ }^{21}$ Thus, the second element of this proposal, whereby the

University of P.R., 864 F.2d 881, 898 (1st Cir. 1988) ("The Meritor] holding leaves open the question of whose perspective . . . should be used in assessing 'unwelcomeness."').

${ }^{218}$ See Lipsett, 864 F.2d at 898.

219 Cathleen M. Mogan, Note, Current Hostile Environment Sexual Harassment Law: Time to Stop Defendants from Having Their Cake and Eating It Too, 6 NOTRE DAME J.L. ETHICS \& PUB. POL'Y 543, 571 (1992).

${ }^{220}$ See Christopher P. Barton, Note, Between the Boss and a Hard Place: A Consideration of Meritor Savings Bank v. Vinson and the Law of Sexual Harassment, 67 B.U. L. REV. 445, 473 (1987) ("[T]he defendant should . . . be required to persuade the judge that he can prove that the plaintiff's behavior was directed specifically at him.").

221 Therefore, peer sexual harassment can be claimed by both boys and girls, see 
conduct underlying a sexual harassment claim need not be sexual in nature, is sufficient as long as the conduct is directed at the student because of his or her sex. ${ }^{222}$ Conduct of a nonsexual nature that ridicules females or treats them as inferior would constitute prohibited sexual harassment. Adopting such a standard recognizes that ${ }^{\text {"[i] }}$ ntimidation and hostility toward women because they are women can obviously result from conduct other than explicit sexual advances." ${ }^{223}$ Furthermore, such a standard is consistent with Title IX's purpose of prohibiting differential treatment on the basis of sex.

Fourth, the conduct must be sufficiently severe or pervasive to create an abusive educational environment. The Ninth Circuit developed the severity/frequency test in the employment context. ${ }^{224}$ Under such a test, a single incident may be considered pervasive if it is severe, but less offensive behavior must be more frequent to rise to the level of pervasiveness. ${ }^{225}$ Thus, this element refutes the argument that allowing a suit under Title IX for peer sexual harassment will permit school children to sue for isolated and genuinely trivial conduct. ${ }^{226}$ The pervasive use of

generally supra note 42 (discussing boys as the victims of peer sexual harassment), provided that the harasser and victim are not the same sex and the harassment would not have occurred but for the gender of the victim. The right to sue under Title IX for peer harassment does not apply to same sex harassment. See supra note 19 (quoting the relevant provision of Title IX that prohibits differential treatment "on the basis of sex"). Thus, a meek boy who is harassed by a male "class bully" does not have a cause of action under Title IX for sex discrimination because the meek boy is harassed because of his physical stature, not his gender.

222 See Andrews v. City of Phila., 895 F.2d 1469, 1485 (3d Cir. 1990) (noting that "to make out a case [of sexual harassment] it is "only necessary to show that gender is a substantial factor in the discrimination").

${ }^{223}$ Id. The following is illustrative: "One female student was assigned the duties of foreperson in her shop, and was unable to perform her job because her male [classmates] refused to acknowledge her. The female student received an ' $F$ ' at the end of the week for not fulfilling her responsibilities." WHO'S HURT AND WHO'S LIABLE, supra note 34, at 5 .

${ }^{224}$ See, e.g., Ellison v. Brady, 924 F.2d 872, 878 (9th Cir. 1991) (holding that "the harasser's conduct ... must be pervasive or severe" enough to "create an abusive working environment"); see also King v. Board of Regents, 898 F.2d 533, 537 (7th Cir. 1990) ("Although a single act can be enough, .. . generally, repeated incidents create a stronger claim of hostile environment, with the strength of the claim depending on the number of incidents and the intensity of each incident.").

225 But see Scott v. Sears, Roebuck \& Co., 798 F.2d 210, 211, 213-14 (7th Cir. 1986) (holding that a single slap on the buttocks accompanied by a sexually lewd question was not "severe, debilitating or pervasive" enough to create a hostile environment).

${ }^{226}$ Contrary to what some critics envision, there will not be a litigation explosion 
derogatory terms relating to females, however, should be evidence of a hostile environment, ${ }^{227}$ as should the posting of pornographic pictures. ${ }^{228}$

The question of what perspective to adopt in determining whether the harassment was sufficient to meet the elements of a hostile environment claim is hotly debated. ${ }^{229}$ The Third and Ninth Circuits, as well as a number of federal district courts and state courts, have replaced the gender-neutral "reasonable person" standard with a "reasonable woman" standard as the objective measure of the severity and pervasiveness of alleged sexual harassment of women. ${ }^{230}$ Adoption of such a standard is a response to the popular theory that there is a "wide divergence

if this Comment's proposed cause of action is recognized. Under most circumstances, one incident of sexual harassment, such as an isolated epithet, would not be actionable. It does strike a balance, however: a young girl "need not subject herself to an extended period of demeaning and degrading provocation before being entitled to seek . . . remedies" under Title IX. Carrero v. New York City Hous. Auth., 890 F.2d 569, 578 (2d Cir. 1989).

227 See Andrews v. City of Phila., 895 F.2d 1469, 1485 (3d Cir. 1990) (holding that "pervasive use of derogatory and insulting terms . . . may serve as evidence of a hostile environment ${ }^{\text {"); }}$ Lipsett v. University of P.R., 864 F.2d 881, 905 (1st Cir. 1988) (finding a hostile working environment where female resident surgeons were subjected to "a constant verbal attack" on their capacity to be surgeons and where the plaintiff was assigned a sexually derogatory nickname by male residents); Katz v. Dole, 709 F.2d 251, 254 (4th Cir. 1983) (finding a hostile environment "pervaded with sexual slur, insult and innuendo").

228 See Andrews, 895 F.2d at 1485; Bennett v. Corroon \& Black Corp., 845 F.2d 104, 106 (5th Cir. 1988) ("Any reasonable person would have to regard these [obscene] cartoons as highly offensive to a woman. ... This is a perfect matrix to grow [a] hostile environment subjecting a woman to . . . discriminatory intimidation, ridicule, and insult . . . ."), cert. denied, 489 U.S. 1020 (1989).

${ }^{229}$ Recently, the Supreme Court agreed to consider the question of which standard should be used when determining if allegations of sexual harassment rise to the level of creating a hostile work environment. See Harris v. Forklift Sys., Inc., No. 92-1168, 1993 U.S. LEXIS 1937 (U.S. 1993). The Sixth Circuit agreed with the district court that continuous inappropriate comments will rise to the level of creating a hostile work environment when the conduct "seriously affect[s] plaintiff's psychological well-being" rather than when the conduct would offend the reasonable woman. Harris v. Forklift Sys., Inc., No. 3:89-0557, 1990 U.S. Dist. LEXIS 20115, at *17-*18 (M.D. Tenn. 1990), affd without opinion, 976 F.2d 733 (6th Cir. 1992), cert. granted, No. 92-1168, 1993 U.S. LEXIS 1937 (U.S. 1993).

${ }^{230}$ See Ellison v. Brady, 924 F.2d 872, 879 (9th Cir. 1991) (holding that "a female plaintiff states a prima facie case of hostile environment sexual harassment when she alleges conduct which a reasonable woman would consider sufficiently severe . . . to ... create an abusive working environment" (footnote omitted)); Andrews, 895 F.2d at 1482-83 (holding that one component of a successful claim for a sexually hostile work environment is harassment that would detrimentally affect a reasonable person of the same sex as the victim). 
between most women's views of appropriate sexual conduct and those of men." 231 Courts have also justified the reasonable woman standard on the ground that "a sex-blind reasonable person standard tends to be male-biased and tends to systematically ignore the experiences of women." 232 Others have suggested alternatives "more in line with a gender neutral approach [such as a reasonable] 'victim,' 'target,' or 'person"' standard. ${ }^{233}$

Admittedly, the debate is over semantics yet the significance of the choice of words should not be underestimated. With regard to peer harassment cases, it would be most appropriate to adopt a "reasonable victim" standard. Title IX was created to eliminate differential treatment of males and females, not to generate and maintain it. ${ }^{234}$ Peer sexual harassment is perpetuated by manipulating doctrines to embrace female stereotypes. The "reasonable woman" standard assumes that all women perceive behavior alike and that all women share similar personality traits. ${ }^{235}$ "[A] definition ... that pits [this female] against that ideal, that pits one woman against the rest," preserves the operation of sexism in the law. ${ }^{236}$ Furthermore, an approach that "encourage[s] different standards of conduct for different groups of people [can become] a potential tool in the hands of the currently dominant group. ${ }^{237}$ The elimination of sexual harassment hinges on a societal transformation where the barriers of age-old stereotypes and prejudices are broken down. Neither the law nor schools nor employers can legislate mindsets, but the law can facilitate social change. The "reasonable victim" standard suggests that male peer harassers base their behaviors on the perspective of the victim-the young woman student-and thus, encourages males to treat females with concern and respect.

Nevertheless, the application of the "reasonable victim" standard should yield the same outcome as the reasonable person standard.

231 Rabidue v. Osceola Refining Co., 805 F.2d 611, 626 (6th Cir. 1986) (Keith, J., concurring in part, dissenting in part); see also supra notes $64-71$ and accompanying text (describing differences of perception between males and females).

232 Ellison, 924 F.2d at 879.

${ }^{233}$ Id. at 884 (Stephens, J., dissenting); see also Mogan, supra note 219, at 566-67 (suggesting a "reasonable victim" or a "new improved" reasonable person standard). ${ }_{234}$ See supra note 182 (discussing the intended purposes of Title IX).

235 Such an assumption is false. Education, social conditioning, maturity, sexual experience, and political awareness all play a part in a woman's or girl's perception of what constitutes sexual harassment.

${ }^{236}$ Susan Estrich, Sex at Work, 43 STAN. L. REV. 813, 815 (1991).

237 Mogan, supra note 219, at 567. 
The reasonable person standard theoretically takes account of gender-based differences because a reasonable woman is a reasonable person. The problem lies in the fact that Americans, in general, do not recognize these differences, and it is the average American who serves on a jury and applies the reasonable person standard. Thus, the average juror may "trivializ[e] the effects of sexual harassment" ${ }^{238}$ on a female and cling to "ingrained notions of reasonable behavior fashioned by ... [average male] offenders." ${ }^{239}$ The "reasonable victim" standard merely highlights the fact that there may be perceptual differences between victim and harasser, thereby focusing the analysis for the jurors.

Finally, the student must show that school officials knew, or should have known, of the charged sexual harassment and failed to implement prompt and appropriate remedial action. Under this proposal, the burden is placed on the school to discourage and eliminate sexual harassment. This responsibility is consonant with a school's duty under Title IX to provide equal educational opportunities. ${ }^{240}$ It is the same responsibility given to an employer for the acts of its employees. ${ }^{241}$ Although it is unrealistic to hold a school accountable for every isolated incident of sexual harassment, it is not an unfair burden on a school to take measures to prevent a sexually hostile atmosphere from pervading a school that both males and females attend. Equally applicable to the educational environment, one court commented in the employment context:

"It may not always be within an employer's power to guarantee an environment free from all bigotry. He cannot change the personal beliefs of his employees; he can let it be known, however, that ... harassment will not be tolerated, and he can take all reasonable measures to enforce this policy. ${ }^{.242}$

${ }^{238}$ Ellison v. Brady, 924 F.2d 872, 879 (9th Cir. 1991).

${ }^{299}$ Rabidue v. Osceola Refining Co., 805 F.2d 611, 626 (6th Cir. 1986) (Keith, J., concurring in part, dissenting in part).

240 See 20 U.S.C. $\$ 1681$ (1988).

241 See, e.g., Lipsett v. University of P.R., 864 F.2d 881, 901 (1st Cir. 1988) (placing responsibility on an educational institution under Title IX to address "hostile environment sexual harassment perpetuated by its supervisors upon employees" where it knew or reasonably should have known about it "unless that official can show that he or she took appropriate steps to halt it"); Rabidue, 805 F.2d at 621 (requiring employers under Title VII to respond to hostile-environment sexual harassment about which they knew or reasonably should have known).

242 Davis v. Monsanto Chem. Co., 858 F.2d 345, 350 (6th Cir. 1988) (quoting DeGrace v. Rumsfeld, 614 F.2d 796, 805 (1st Cir. 1980)) (explaining the burden 
The same type of policy can be implemented in the educational environment. "By informing people that the expression of ... sexist attitudes in public is unacceptable, people [including our children] may eventually learn that such views are undesirable in private, as well." 243 Schools that ignore peer sexual harassment or condone it with the attitude that "boys will be boys" effectively teach young men that such behavior is acceptable. Thus, if the proposed cause of action is recognized, Title IX may help to eliminate prejudices and biases in our schools as Title VII has done in the workplace.

For a school to be held liable under this proposal, the student must prove that the school, through its officials, knew or should have known of the charged sexual harassment. School officials should include administrators such as the principal, vice-principal, dean and chairperson of a department, guidance counselors, and teachers. The school's knowledge may be shown through complaints that were lodged with the school ${ }^{244}$ or by demonstrating that the harassment was so pervasive that the school's awareness may be inferred. ${ }^{245}$ Except in those cases where the school should have been aware of the harassment, this places the burden on the victim to come forward and relieves the school of strict liability for all sexual harassment inflicted or suffered. ${ }^{246}$

When school officials receive knowledge of sexual harassment, the proposed cause of action would provide an incentive for them to promptly investigate the complaint and impose sufficient

placed on employers under Title VII in reference to racial harassment).

${ }^{243}$ Davis, 858 F.2d at 350.

${ }^{244}$ Under Title IX, the school is required to implement and publicize an operational grievance procedure. See supra note 133 and accompanying text. A student complaint that does not comply with the specific procedures should nevertheless qualify as notice to the school. The purpose of the procedures is to make the complaint process simpler and not to create procedural hurdles for the student. As long as the school receives notice, the manner of communication should be irrelevant.

${ }^{245}$ Under Title VII, employers are held liable for failing to remedy or prevent a hostile environment if, in the exercise of reasonable care, they should have known that the environment was hostile to workers. See, e.g., Andrews v. City of Phila., 895 F.2d 1469, 1486 (3d Cir. 1990) ("We do not consider it an unfair burden of an employer of both genders to take measures to prevent an atmosphere of sexism to pervade the workplace"); Trotta v. Mobile Oil Corp., 788 F. Supp. 1336, 1351 (S.D.N.Y 1992) (making a comparison to agency principles).

${ }^{246}$ It also places a duty on school personnel to recognize peer sexual harassment and intervene, thereby encouraging the school to provide sexual harassment training for their staff. 
penalties to ensure an educational environment free from sexual hostility. ${ }^{247}$ Essentially, this is equivalent to the standard imposed upon employers under Title VII. ${ }^{248}$ The school's remedial action "should be 'reasonably calculated to end the harassment." 249 The exact scope of the school's disciplinary response would be up to the school officials, guided only by the caveat that it should be "assessed proportionately to the seriousness of the offense." 250 For instance, a first offense might require a parent conference or an apology to the victim, whereas repeated offenses might demand detention, suspension, or expulsion.

Some critics argue that permitting a cause of action for peer sexual harassment sends a harmful message that females are victims and encourages them to let the courts fight their battles for them. ${ }^{251}$ That argument goes to the core meaning of sexual harassment and exposes a common misconception. Peer sexual harassment is behavior that a student cannot "turn off"-she cannot stop it simply by not responding-at least not without the risk of some type of physical or social repercussion and, as such, "may be better conceptualized as an act of aggression than as a sexual act." ${ }^{252}$ Sexual harassment intimidates, dominates, and frightens the victim. In fact, the law already acknowledges this by protecting females in the workplace from hostile environments. ${ }^{253}$ More-

247 A similar standard has already been applied by the U.S. Department of Education's Office for Civil Rights. In the case of Tawnya Brawdy, the girl who consistently faced boys mooing at her in school, the Department found that the school failed to protect her because the school did not take her complaint seriously. See Sally Jessy, supra note 10, at 2. In fact, the school decided to revise their sexual harassment policy after agreeing to pay her $\$ 20,000$ to settle her case. See Anderson, supra note 92 , at $\mathrm{B1}$.

${ }^{248}$ See, e.g., Ellison v. Brady, 924 F.2d 872, 882 (9th Cir. 1991) (employers under Title VII should impose penalties calculated to end harassment); EEOC v. Hacienda Hotel, 881 F.2d 1504, 1516 (9th Cir. 1989) (mere existence of grievance procedure and antidiscrimination policy is insufficient if not invoked).

${ }^{249}$ Ellison, 924 F.2d at 882 (quoting Katz v. Dole, 709 F.2d 251, 256 (4th Cir. 1983)); see Intelkofer v. Turnage, 973 F.2d 773, 777 (9th Cir. 1992) (quoting the Ellison rationale for calculating damages or determining remedial action).

${ }^{250}$ Ellison, 924 F.2d at 882 (quoting Dornhecker v. Malibu Grand Prix Corp., 828 F.2d 307, 309 (5th Cir. 1987)).

251 See Leo, supra note 97 , at 17 ("The most harmful message, perhaps, is that women are victims; incapable of dismissing creeps with a simple 'Buzz off, Bozo' ...."); Debbie M. Price, Victims of Their Gender?, L.A. DAILY J., Mar. 24, 1992, at 6 ("Are we turning our girls into sniveling emotional cripples who see themselves as victims... ?").

252 Bogart \& Stein, supra note 186, at 147.

253 See Meritor Sav. Bank v. Vinson, 477 U.S. 57, 73 (1986) (holding that "a claim of 'hostile environment' sex discrimination is actionable under Title VII"). 
over, it is better to encourage nonviolent means to solve peer sexual harassment problems. ${ }^{254}$

In light of the Court's granting of Title IX monetary damage awards in Franklin v. Gwinnett County Public Schools, ${ }^{255}$ schools will now find it of even greater importance to provide equal education to all students as mandated under Title IX. Permitting a cause of action for peer sexual harassment under Title IX will allow victims to sue for money damages. Contrary to the contention of critics, the availability of a peer sexual harassment claim under Title IX will not lead to a litigation explosion or frivolous awards. ${ }^{256}$ This Comment's proposed prima facie case limits a school's liability to only those claims where the student can prove both that a hostile environment exists and that the school has failed to take prompt and appropriate corrective action. ${ }^{257}$

\section{CONCLUSION}

The time has come to recognize that student-to-student sexual harassment is a legitimate and pervasive problem in elementary and secondary schools. The widespread existence and acceptance of peer sexual harassment cannot justify its continuance. The adverse

254 Imagine the scenario where young women take the problem of sexual harassment into their hands-and perhaps carry weapons. The scenario is not that farfetched. In 1990, women students at Brown University decided to tackle the problem of harassment on their own. The students scribbled a list on the women's bathroom wall of male students alleged to have harassed, assaulted, or raped woman. See Mark Starr, The Writing on the Wall, NEWSWEEK, Nov. 26, 1990, at 64, 64.

255112 S. Ct. 1028 (1992); see supra notes 172-74 and accompanying text (explaining the facts and legal implications of Franklin).

${ }^{256}$ In fact, research indicates the damage awards in civil rights cases are limited in number and both appropriate and modest in amount. See Civil Rights Act of 1990: Hearings on H.R. 4000 Before the House Comm. on Education and Labor, 101st Cong., 2d Sess. 142-71 (1990) [hereinafter Civil Rights Hearings]. One recent study, examining the propensity of discrimination victims to sue, concluded that:

Far from revealing that potential discrimination claimants are eager to sue, the data show that discrimination victims are substantially less likely to file a legal action than are other disputants. The notion of the existence of a huge army of potential claimants waiting to exploit any marginal change in civil rights laws is not supported by any data.

Id. at 152-53 (testimony of Theodore Eisenberg). Indeed, this conclusion is supported by a review of civil rights filings following the enactment of the Civil Rights Attorneys Fees Awards Act, 42 U.S.C. § 1988 (1988). The data show that civil rights filings covered by the Act increased at a substantially lower rate than other filings. See Civil Rights Hearings, supra, at 153.

257 Theoretically, a school could not be held liable for sexual harassment incidents that persisted if the school took reasonable corrective actions. 
effects of peer sexual harassment on a female student's education and consequently, her career and economic potential, demands serious attention and warrants relief.

Because schools frequently ignore, trivialize, or condone peer sexual harassment complaints, and because adequate state sexual harassment remedies often do not exist, this Comment advocates that Title IX should provide a student an avenue for redress. Title IX supports a claim for peer sexual harassment because the statute prohibits differential treatment of students on the basis of sex. Peer sexual harassment that creates a hostile environment in a school setting should be actionable under Title IX as it is in the workplace under Title VII. Although relatively few cases involving claims of sexual harassment under Title IX exist, Title VII case law and standards can provide a basis for developing a framework to evaluate student-to-student sexual harassment. Schools that do not establish workable sexual harassment policies and procedures and do not respond effectively to peer sexual harassment complaints expose themselves to liability by failing to comply with their legal duty under Title IX.

More importantly, the operation of Title IX can serve an educational purpose. The law molds people's behavior by defining proper conduct. Permitting a cause of action for peer sexual harassment by holding schools liable under Title IX sends a clear signal to society that such behavior will not be tolerated and is simply unacceptable whether it be between men and women in the workplace or boys and girls in the classroom or schoolyard. Addressing the issue of peer sexual harassment and holding people accountable for their behavior is the key to teaching males and females how to treat each other with equal respect and dignity. 